Review

\title{
Strategizing Carbon-Neutral Mines: A Case for Pilot Projects
}

Ian M. Power ${ }^{1, *}$, Jenine McCutcheon ${ }^{2}$, Anna L. Harrison ${ }^{1}$, Siobhan A. Wilson ${ }^{3}$, Gregory M. Dipple ${ }^{1}$, Simone Kelly ${ }^{4}$, Colette Southam ${ }^{4}$ and Gordon Southam ${ }^{2}$

1 Mineral Deposit Research Unit, Department of Earth, Ocean and Atmospheric Sciences, The University of British Columbia, 2207 Main Mall, Vancouver, BC V6T 1Z4, Canada; E-Mails: aharriso@eos.ubc.ca (A.L.H.); gdipple@eos.ubc.ca (G.M.D.)

2 School of Earth Sciences, The University of Queensland, St. Lucia, QLD 4072, Australia;

E-Mails: j.mccutcheon@uq.edu.au (J.M.); g.southam@uq.edu.au (G.S.)

3 School of Geosciences, Monash University, Clayton, VIC 3800, Australia;

E-Mail: sasha.wilson@monash.edu

4 Department of Finance, Bond University, Robina, QLD 4229, Australia;

E-Mails: skelly@bond.edu.au (S.K.); csoutham@bond.edu.au (C.S.)

* Author to whom correspondence should be addressed; E-Mail: ipower@eos.ubc.ca; Tel.: +1-604-822-2449; Fax: +1-604-822-6088.

Received: 4 March 2014; in revised form: 22 April 2014 / Accepted: 24 April 2014 /

Published: 2 May 2014

Abstract: Ultramafic and mafic mine tailings are a valuable feedstock for carbon mineralization that should be used to offset carbon emissions generated by the mining industry. Although passive carbonation is occurring at the abandoned Clinton Creek asbestos mine, and the active Diavik diamond and Mount Keith nickel mines, there remains untapped potential for sequestering $\mathrm{CO}_{2}$ within these mine wastes. There is the potential to accelerate carbonation to create economically viable, large-scale $\mathrm{CO}_{2}$ fixation technologies that can operate at near-surface temperature and atmospheric pressure. We review several relevant acceleration strategies including: bioleaching of magnesium silicates; increasing the supply of $\mathrm{CO}_{2}$ via heterotrophic oxidation of waste organics; and biologically induced carbonate precipitation, as well as enhancing passive carbonation through tailings management practices and use of $\mathrm{CO}_{2}$ point sources. Scenarios for pilot scale projects are proposed with the aim of moving towards carbon-neutral mines. A financial incentive is necessary to encourage the development of these strategies. We recommend the use of a dynamic real options pricing approach, instead of traditional discounted cash-flow approaches, because it reflects the inherent value in managerial 
flexibility to adapt and capitalize on favorable future opportunities in the highly volatile carbon market.

Keywords: carbon sequestration; carbon mineralization; mineral carbonation; bioleaching; biomineralization; mine tailings; magnesium carbonate; greenhouse gas emissions; carbon market; real options valuation

\section{Introduction}

Mines that generate ultramafic and mafic mine wastes (e.g., tailings) have the capacity to more than offset their greenhouse gas $(\mathrm{GHG})$ emissions by sequestering carbon dioxide $\left(\mathrm{CO}_{2}\right)$ via carbon mineralization to create an environmental benefit while utilizing a waste product. Carbon mineralization, also known as mineral carbonation, involves the reaction of $\mathrm{CO}_{2}$ with alkaline earth metal bearing silicate and hydroxide minerals to form carbonate minerals, thereby storing $\mathrm{CO}_{2}$ in a stable form. Rapid conversion of naturally occurring ultramafic and mafic minerals at high temperature and high pressure using industrial reactors is technologically feasible (e.g., [1,2]); however, the costs of mineral pre-treatment and the energy economics of accelerating carbonation reactions from geological to industrial timescales remain serious obstacles [3].

Economic viability is critical for the adoption and eventual commercialization of new processes within the mining sector as it must be cost-effective from a user perspective and must provide an acceptable return for investors. Because of the energy intensity required for mining and processing natural bedrock and carbonation in industrial reactors, the International Energy Agency has ruled out the likelihood of adopting carbon mineralization processes; traditional valuation methodologies estimate their cost for fixing one tonne of $\mathrm{CO}_{2}$ to be between $\$ 50$ and $\$ 100$ U.S. [4], far exceeding current world carbon prices, which range from the European Union Emissions Trading System (EU ETS; floating) price of approximately $\$ 6$ U.S. to the UK carbon price floor (fixed) price of approximately \$28 U.S. In addition to economic incentives, reducing GHG emissions will likely contribute to ensuring mining companies maintain their "social license to operate" [5].

To overcome economic impediments, considerable research has focused on developing and accelerating carbonation processes using alkaline rocks and waste materials under low temperature and pressure conditions [6-10]. Specifically, numerous studies have explored the use of ultramafic mine wastes as a potentially valuable feedstock for carbon mineralization [11-29]. Ultramafic and mafic mines generate vast quantities of mine tailings that offer a readily available, fine-grained feedstock for carbonation. As an indication of their reactivity, passive carbonation of ultramafic tailings has been documented at several sites under normal mining conditions [11,17,18,20,21,24,26,30]. Tailings storage facilities (TSFs) for ultramafic and mafic mine wastes are typically designed solely to hold tailings and recycle process water. In contrast, sulfidic mine tailings require a more sophisticated TSF design to prevent the generation of acid mine drainage [31]. Carbonation of ultramafic mine wastes could be accelerated by implementing strategies that enhance mineral dissolution, increase $\mathrm{CO}_{2}$ supply, and facilitate carbonate precipitation at near-surface conditions using TSF design strategies that promote carbonation. 
We review some of the proposed biotic and abiotic acceleration strategies including: bioleaching of $\mathrm{Mg}$-silicates; increasing the supply of $\mathrm{CO}_{2}$ via heterotrophic oxidation of waste organics, altering tailings management practices, and use of point sources with elevated $\mathrm{CO}_{2}$ partial pressures $\left(p \mathrm{CO}_{2}\right)$; and biologically induced carbonate precipitation. Although these strategies have proven effective in laboratory-scale studies (e.g., [13,15,19,28,32,33]), pilot projects are crucially needed to evaluate strategies for accelerating carbon mineralization, which if successful and cost effective could be incorporated into TSF design with the purpose of sequestering $\mathrm{CO}_{2}$. Discussion of these strategies is followed by the proposal of two scenarios for pilot projects, which if implemented at the mine-scale could render some mining operations carbon-neutral. We provide estimates of the operational costs of the proposed scenarios on a dollar per tonne of $\mathrm{CO}_{2}$ basis and recommend the use of a real options valuation model (comparable to what one might use to price a biotechnology start-up) to better assess the potential of carbon mineralization strategies.

\section{Mine Sites: Untapped Potential to Sequester $\mathrm{CO}_{2}$}

The mining industry is a major GHG emitter (e.g., [34]), and certain mines have the untapped capacity to significantly or completely offset their GHG emissions. Ultramafic and mafic mines generate massive quantities of tailings that are rich in $\mathrm{Mg}$-silicate and hydroxide minerals such as the serpentine polymorphs chrysotile, lizardite and antigorite $\left[\mathrm{Mg}_{3} \mathrm{Si}_{2} \mathrm{O}_{5}(\mathrm{OH})_{4}\right]$, olivine group minerals such as forsterite $\left[\mathrm{Mg}_{2} \mathrm{SiO}_{4}\right]$, and highly reactive oxides and hydroxide phases, e.g., brucite $\left[\mathrm{Mg}(\mathrm{OH})_{2}\right]$. These tailings, which are otherwise a waste product, are a potentially valuable mineral feedstock for carbon mineralization because of their quantity, mineralogical composition, and high reactive surface areas that are generated during ore processing. Although felsic tailings may also act as mineral feedstock for carbonation reactions, ultramafic and mafic mine wastes have been the focus of most studies as these wastes are more reactive (e.g., [18,25]).

Global production of nickel, platinum group metals, asbestos, diamond, chromite, and talc generates $\sim 419$ Mt of ultramafic and mafic mine tailings annually [35]. Assuming complete carbonation, this provides the potential to sequester $\sim 175 \mathrm{Mt} \mathrm{CO}_{2} /$ year [35]. On the scale of individual mining operations, certain mines have the capacity to more than offset their own GHG emissions, thereby providing a sink for other emissions sources. For example, complete carbonation of the $\sim 11 \mathrm{Mt}$ of tailings generated annually at the Mount Keith nickel mine in Western Australia [36] would sequester $\sim 4 \mathrm{Mt} \mathrm{CO}_{2}$ /year as magnesium carbonate minerals such as hydromagnesite $\left[\mathrm{Mg}_{5}\left(\mathrm{CO}_{3}\right)_{4}(\mathrm{OH})_{2} \cdot 4 \mathrm{H}_{2} \mathrm{O}\right]$. This represents a capture capacity of approximately 10 times the annual emissions generated by the mine. Although passive carbonation of mine tailings have been documented at mine sites under normal mining conditions, such as those at the Mount Keith nickel mine, the bulk of their capacity to sequester $\mathrm{CO}_{2}$ remains untapped.

\subsection{Comparative Studies of Ultramafic Mines}

Our research investigating carbon mineralization at mine sites has focused largely on three sites: the abandoned Clinton Creek asbestos mine, and the active Diavik diamond and Mount Keith nickel mines (Figure 1). These mines have formed the basis of field, laboratory, and geochemical modeling studies aimed at developing the capacity to better utilize mine wastes as carbon sinks [11,13,15-21,28,37-40]. 
It is from this research that much of our understanding of carbon mineralization at mine sites and acceleration strategies are drawn. Each of these sites is characterized by distinct climatic and hydrological conditions and different tailings management practices, all of which have an impact on the rate and extent of carbon mineralization. Because the tailings from all three sites are mineralogically similar, it is possible to identify factors that enhance as well as limit weathering and carbonation of Mg-rich gangue minerals (Table 1).

Figure 1. Tailings storage facilities (TSF) for ultramafic tailings. (a) Abandoned Clinton Creek asbestos mine in Yukon, Canada. Inset shows vertical efflorescent crust cementing chrysotile tailings (marker for scale). (b) Active Diavik diamond mine in Northwest Territories, Canada. Inset shows an efflorescent crust on surface of tailings (marker for scale). (c) Active Mount Keith nickel mine in Western Australia. Inset shows a surface efflorescent crust held up to show cross-sectional view (knife for scale). These carbonate crusts have formed from passive carbonation under normal mining conditions.
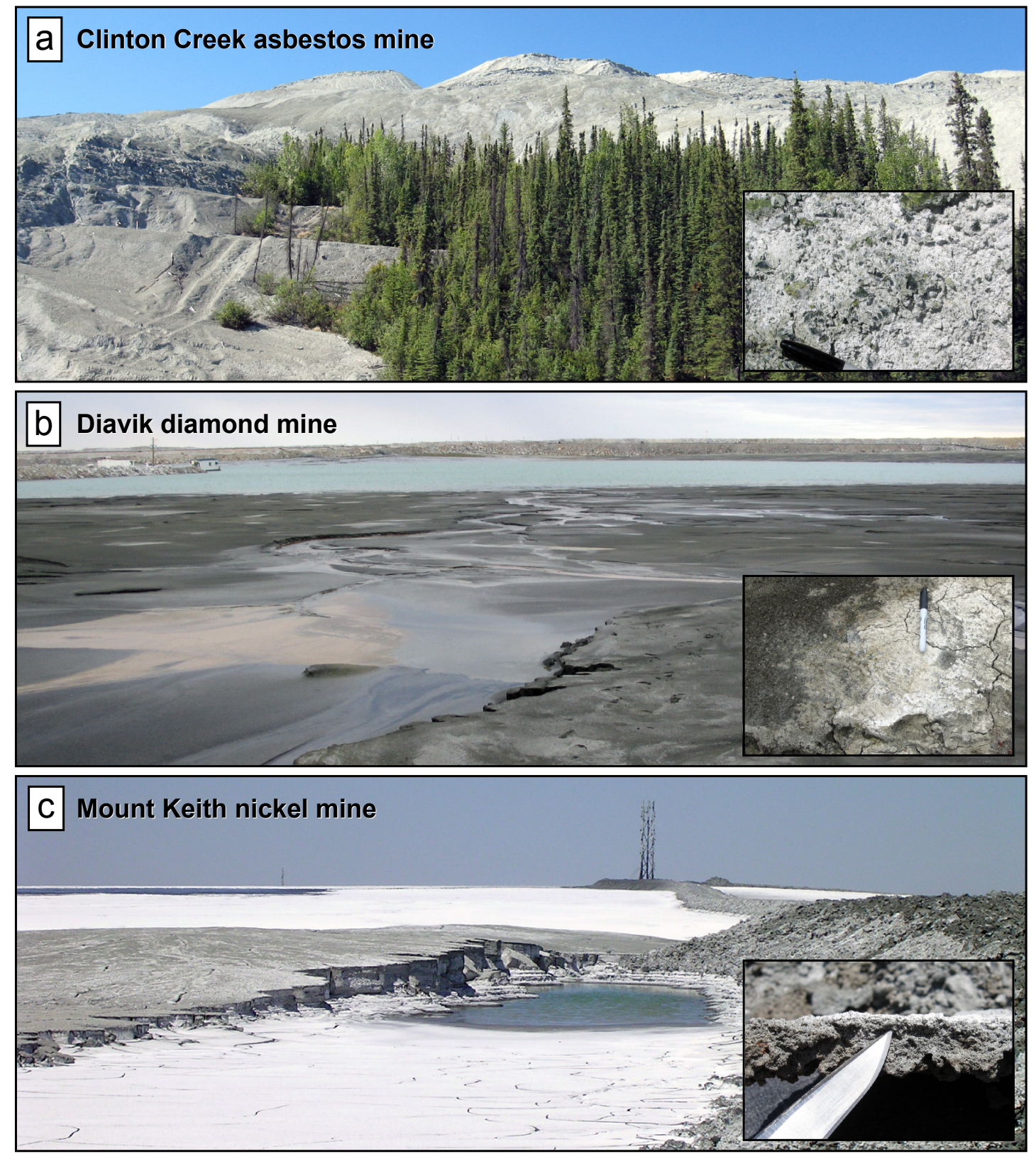
Table 1. Mine sites investigated for carbon mineralization.

\begin{tabular}{|c|c|c|c|}
\hline Mine Site & Clinton Creek & Diavik & Mount Keith \\
\hline $\begin{array}{l}\text { Location } \\
\text { Commodity }\end{array}$ & $\begin{array}{l}\text { Yukon, Canada } \\
\text { asbestos (abandoned) }\end{array}$ & $\begin{array}{l}\text { Northwest Territories, Canada } \\
\text { diamonds (active) }\end{array}$ & $\begin{array}{l}\text { Western Australia } \\
\text { nickel (active) }\end{array}$ \\
\hline \multicolumn{4}{|l|}{ Environmental data $[13,36,41]$} \\
\hline Climate & subarctic & subarctic & desert \\
\hline $\begin{array}{l}\text { Mine site GHG emissions } \\
\left(\mathrm{kt} \mathrm{CO}_{2} \mathrm{e} / \text { year) }\right.\end{array}$ & $\mathrm{n} / \mathrm{a}$ & 219 & 382 \\
\hline $\begin{array}{l}\text { Onsite power generation } \\
\left(\mathrm{CO}_{2} \text { point source }\right)\end{array}$ & $\mathrm{n} / \mathrm{a}$ & yes & yes \\
\hline Water usage (ML) & $\mathrm{n} / \mathrm{a}$ & $\begin{array}{l}376 \text { directed to TSF } \\
72 \text { treated sewage to TSF } \\
\text { 12,491 discharged to Lac de Gras }\end{array}$ & $\begin{array}{l}9,534 \text { in total } \\
1,651 \text { high quality } \\
186 \text { treated sewage effluent }\end{array}$ \\
\hline Tailings production & $\sim 11 \mathrm{Mt}$ in total & $\sim 2 \mathrm{Mt} / \mathrm{year}$ & $\sim 11 \mathrm{Mt} /$ year \\
\hline Process water $[\mathrm{Mg}+\mathrm{Ca}](\mathrm{mg} / \mathrm{L})$ & $\sim 160$ (pore water) & $\sim 40$ & $\sim 3,500$ \\
\hline \multicolumn{4}{|l|}{ Mineralogical data $[15,20]$} \\
\hline Major minerals & chrysotile ( $\sim 88$ wt \%) & $\begin{array}{l}\text { lizardite }(48 \mathrm{wt} \%) \\
\text { forsterite }(25 \mathrm{wt} \%)\end{array}$ & $\begin{array}{l}\text { antigorite/lizardite } \\
(\sim 81 \mathrm{wt} \%)\end{array}$ \\
\hline Minor minerals & $\begin{array}{l}\text { dolomite, magnesite, } \\
\text { quartz, magnetite, } \\
\text { pyroaurite }\end{array}$ & $\begin{array}{l}\text { vermiculite, phlogopite, calcite, } \\
\text { muscovite, plagioclase, quartz, } \\
\text { diopside, almandine-pyrope }\end{array}$ & $\begin{array}{l}\text { iowaite, magnesite, woodallite, } \\
\text { magnetite, chromite, dolomite, } \\
\text { chrysotile }\end{array}$ \\
\hline $\begin{array}{l}\text { Highly reactive phases for } \\
\text { carbon mineralization }\end{array}$ & trace brucite & $\mathrm{n} / \mathrm{a}$ & brucite $(\sim 2.5$ wt \%) \\
\hline $\begin{array}{l}\mathrm{MgO}(\%) \\
\text { Secondary Mg-carbonates } \\
\text { from passive carbonation }\end{array}$ & $\begin{array}{l}\sim 37 \% \\
\text { nesquehonite, dypingite, } \\
\text { hydromagnesite, } \\
\text { lansfordite }\end{array}$ & $\begin{array}{l}\sim 33 \% \\
\text { nesquehonite }\end{array}$ & $\begin{array}{l}\sim 40 \% \\
\text { hydromagnesite }\end{array}$ \\
\hline \multicolumn{4}{|c|}{ Carbon mineralization $[11,17-19]$} \\
\hline $\begin{array}{l}\text { Passive carbonation rate } \\
\left(\mathrm{g} \mathrm{CO}_{2} / \mathrm{m}^{2} / \text { year }\right)\end{array}$ & $\sim 6,200$ & $374-418$ & 2,400 \\
\hline $\begin{array}{l}\text { GHG emission offset from } \\
\text { passive carbonation }\end{array}$ & $\begin{array}{l}\sim 82 \mathrm{kt} \mathrm{CO}_{2} \text { total }(1978 \\
\text { to } 2004)\end{array}$ & $\sim 0.2 \%$ of total GHG emissions & $\sim 11 \%$ of total GHG emissions \\
\hline $\begin{array}{l}\text { Potential GHG emissions offset } \\
\text { based on full carbonation } \\
\left(\mathrm{kt} \mathrm{CO}_{2}\right) \text { to hydromagnesite }\end{array}$ & $\begin{array}{l}\sim 3,700 \mathrm{kt} \mathrm{CO}_{2} \text { in total } \\
\text { from chrysotile }\end{array}$ & $\begin{array}{l}\sim 670 \mathrm{kt} / \text { year from lizardite; } \\
\sim 230 \mathrm{kt} / \mathrm{year} \text { from forsterite }\end{array}$ & $\begin{array}{l}3,400 \mathrm{kt} / \text { year from } \\
\text { antigorite/lizardite; } \\
166 \mathrm{kt} / \text { year from brucite }\end{array}$ \\
\hline
\end{tabular}

Clinton Creek is located in the subarctic, $\sim 80 \mathrm{~km}$ northwest of Dawson City, Yukon, Canada. The mine produced approximately $11 \mathrm{Mt}$ of chrysotile dominated tailings (Table 1) during its operational lifetime from 1967 to 1978 [21]. The tailings pile was initially situated on a hilltop overlooking a creek, but has since slumped downslope to cover the hillside (Figure 1a).

Of the two active mines studied, the Diavik diamond mine, another subarctic site, is located approximately $300 \mathrm{~km}$ northeast of Yellowknife, Northwest Territories, Canada. Most of the residual kimberlite waste ( $2 \mathrm{Mt}$ /year; dominantly lizardite and forsterite) is piped as slurry into a natural basin used as a TSF [17]. The tailings are partially submerged in a pond in the center of the basin (Figure 1b). The Mount Keith nickel mine is located in the desert of Western Australia, $\sim 630 \mathrm{~km}$ 
northeast of Perth. It produces $\sim 11 \mathrm{Mt}$ of tailings per year that are transported as a suspension in hypersaline process water $([\mathrm{Mg}+\mathrm{Ca}] \approx 3500 \mathrm{mg} / \mathrm{L})$ and deposited from nine risers in a TSF that is $\sim 16.6 \mathrm{~km}^{2}$ in area (Figure 1c). The TSF has a slight slope from the natural topography, allowing process water to be collected and recycled. Antigorite and lizardite comprise the majority of the tailings and brucite, a highly reactive phase, is present at minor abundance (Table 1).

The Diavik mine emitted $\sim 219 \mathrm{kt}$ of $\mathrm{CO}_{2}$ equivalent $\left(\mathrm{CO}_{2} \mathrm{e}\right)$ of greenhouse gases in 2011 and the Mount Keith mine emitted $\sim 382 \mathrm{kt}$ of $\mathrm{CO}_{2} \mathrm{e}$ in 2004 [36,41]. Diavik has installed four wind turbines that are expected to reduce $\mathrm{GHG}$ emissions by $6 \%$, suggesting that there is motivation to reduce GHG emissions [41]. Pertinent information regarding these three sites is summarized in Table 1.

\subsection{Passive Carbonation at Mines: Rates and Limitations}

$\mathrm{CO}_{2}$ sequestration at mines results from weathering and carbonation of ultramafic and mafic tailings that are exposed to Earth's surface conditions. We refer to this process as passive carbonation because it occurs without human mediation and is not an intended outcome of the TSF design. Passive carbonation has been documented at Clinton Creek [18,20], Diavik [17,21], and Mount Keith [11,19] as well as other abandoned and active mine sites in Canada, United States, Australia, and Norway [24,26,30,42].

Mineral dissolution rates are significantly increased due to the high reactive surface area of tailings in comparison to natural bedrock, which provides $\mathrm{Mg}$ in solution that is available for carbonation (e.g., [11]). For example, the $\mathrm{Mg}$ concentration of water draining from Clinton Creek chrysotile tailings is $\sim 160 \mathrm{mg} / \mathrm{L}$ in comparison to the natural background $\mathrm{Mg}$ concentration in local creek water of $\sim 70 \mathrm{mg} / \mathrm{L}$ [13]. Evapoconcentration and uptake of atmospheric $\mathrm{CO}_{2}$ into tailings pore waters can result in the precipitation of hydrated Mg-carbonate minerals (Equation (1); e.g., hydromagnesite), which are common low-temperature weathering products of natural serpentine minerals and brucite (e.g., $[43,44])$.

$$
5 \mathrm{Mg}^{2+}+4 \mathrm{CO}_{3}^{2-}+2 \mathrm{OH}^{-}+4 \mathrm{H}_{2} \mathrm{O} \stackrel{\text { Evap. }}{\longrightarrow} \mathrm{Mg}_{5}\left(\mathrm{CO}_{3}\right)_{4}(\mathrm{OH})_{2} \cdot 4 \mathrm{H}_{2} \mathrm{O}
$$

Although these phases are metastable compared to magnesite $\left[\mathrm{MgCO}_{3}\right]$, precipitation of hydrated Mg-carbonate minerals occurs more readily due to kinetic limitations on magnesite precipitation at near-surface temperatures (e.g., $<60{ }^{\circ} \mathrm{C}$ ) $[45,46]$. Thus, metastable phases including lansfordite $\left[\mathrm{MgCO}_{3} \cdot 5 \mathrm{H}_{2} \mathrm{O}\right]$, nesquehonite $\left[\mathrm{MgCO}_{3} \cdot 3 \mathrm{H}_{2} \mathrm{O}\right]$, dypingite $\left[\mathrm{Mg}_{5}\left(\mathrm{CO}_{3}\right)_{4}(\mathrm{OH})_{2} \cdot 5 \mathrm{H}_{2} \mathrm{O}\right]$, and hydromagnesite typically form from weathering of ultramafic mine tailings [11,18,20,21,26]. Mg-carbonate minerals commonly form at tailings surfaces as efflorescent crusts (insets in Figure 1), thick hardpans, and at depth within tailings as cement between mineral grains [18].

The rate of passive carbonation depends on the characteristics of the tailings (e.g., mineralogy and grain size), climatic conditions (e.g., temperature and precipitation), process and pore water chemistry, and the design of the TSF. The tailings at the abandoned Clinton Creek mine have sequestered an average of $6200 \mathrm{~g} \mathrm{CO}_{2} / \mathrm{m}^{2} /$ year within hydrated $\mathrm{Mg}$-carbonate minerals since the mine closed in 1978 (Table 1) [18,47]. This rate is based on analyses of the upper $\sim 1 \mathrm{~m}$ of tailings where exposure to atmospheric $\mathrm{CO}_{2}$ would be greatest. In contrast, natural uptake of atmospheric $\mathrm{CO}_{2}$ during silicate weathering in river catchments in the Russian and Canadian arctic and subarctic is estimated to be 4.4-10.3 $\mathrm{g} \mathrm{CO}_{2} / \mathrm{m}^{2} /$ year $[48,49]$. The elevated weathering rates observed at Clinton Creek are a consequence of the subaerial exposure of the fine-grained tailings and spreading of the pile due to 
slumping. Although the climatic conditions are similar at Diavik, passive carbonation at this site only sequesters an estimated 374-418 $\mathrm{g} \mathrm{CO}_{2} / \mathrm{m}^{2} /$ year [21]. Here, reaction rates are limited by the TSF design, which has the majority of tailings submerged in a pond. Passive carbonation rates of $2400 \mathrm{~g} \mathrm{CO}_{2} / \mathrm{m}^{2} /$ year are estimated at Mount Keith in an operational central discharge TSF [19], which offsets annual mine emissions by $\sim 11 \%$ [19]. Rates are likely faster at Mount Keith than at Diavik because of its warm, dry climate (i.e., high evaporation rates), saline water chemistry (i.e., greater cation concentrations), and a TSF design that allows for subaerial exposure of tailings enabling greater ingress of atmospheric $\mathrm{CO}_{2}$ and evapoconcentration of pore waters. These rates of passive carbonation are achieved under non-ideal chemical conditions (e.g., $\mathrm{CO}_{2}$ limited), leaving the majority of tailings un-carbonated. Thus, further carbonation requires acceleration strategies.

\subsection{Evidence for Microbial Activity at Mine Sites}

TSFs are neither designed for carbon mineralization nor as habitats for microbial communities that could facilitate carbon mineralization. However, the possibility of rendering certain mines carbon-neutral, has led to investigation of microbial processes for mediating carbon mineralization within TSFs. Ultramafic and mafic mine tailings typically lack abundant energy sources and/or limiting nutrients for microbes that might otherwise contribute to mineral dissolution and/or precipitation. For instance, microbial counts of heterotrophic bacteria in the Clinton Creek and Mount Keith tailings have modest populations of $10^{1}$ to $10^{5}$ colony forming units $(\mathrm{cfu}) / \mathrm{g}$ as determined by the standard plate count method. In contrast, soils and sediments possessing high microbial activity, typically possess on the order of 10,000 different species of bacteria with total populations of up to $10^{10}$ bacteria/g [50]. At the aforementioned mines, there are examples of microbe-carbonate interactions and microbially mediated processes that could potentially be harnessed to sequester $\mathrm{CO}_{2}$ (Figure 2).

A striking example of microbially mediated carbonate precipitation are the carbonate microbialites found in an open pit pond at Clinton Creek (Figure 2a-c) [37]. These microbialites are columnar (up to $15 \mathrm{~cm}$ tall; Figure $2 \mathrm{~b}$ ) and presumably began forming in the flooded open pit after the mine closed in 1978. Precipitation of aragonite entombs calcifying microbes such as cyanobacteria, which may be observed using scanning electron microscopy (SEM) of acid-etched thin sections (Figure 2c) [37]. At Diavik and Mount Keith, field observations suggest that process waters in TSFs are oligotrophic and do not support extensive microbial growth. Still, biofilms and microbial mats, dominated by cyanobacteria, are found on pit walls at Diavik (Figure $2 \mathrm{~d}-\mathrm{f}$ ) and within drainage channels at Mount Keith (Figure 2g-i), respectively. Exposing these biological samples to dilute acid while observing under a light microscope generated visible bubbles of $\mathrm{CO}_{2}$ (Figure 2f,i), thereby determining the presence of submicron-scale grains of carbonate minerals amongst non-carbonate grains [51]. These examples of microbe-carbonate interactions suggest that a mining environment can foster microbial communities capable of mediating carbonate precipitation, which introduces a potential biological pathway for sequestering $\mathrm{CO}_{2}$ at mine sites.

\section{Strategies for Accelerating Carbon Mineralization}

Carbon mineralization in mine wastes depends on the rates of mineral dissolution, supply of $\mathrm{CO}_{2}$ into solution, and carbonate precipitation (driven by processes such as evaporation and alkalinity 
generation). Thus, strategies to accelerate carbon mineralization must target one or more of these processes (Figure 3) [35]. Passive carbonation under normal mining conditions is limited by the supply of $\mathrm{CO}_{2}$ [11,16]; however, conditions could arise in an acceleration scenario in which mineral dissolution or carbonate precipitation become rate limiting. Thus, strategies that enhance mineral dissolution/precipitation and $\mathrm{CO}_{2}$ supply could be deployed within a TSF alone or in combination. Table 2 summarizes the key processes and considerations of some potential acceleration strategies.

Figure 2. Evidence of microbe-carbonate interactions at Clinton Creek (a-c), Diavik $(\mathbf{d}-\mathbf{f})$ and Mount Keith (g-i). (a) Open pit pond at the Clinton Creek asbestos mine with (b) carbonate microbialites along the pond periphery (marker for scale) (after [37]). (c) scanning electron microscopy (SEM) micrograph of acid-etched thin section revealing filamentous cyanobacteria previously entombed in aragonite. (d) Open pit wall at Diavik showing water drainage (arrow) and biofilms (e) on rock surfaces (width of photograph is $\sim 30 \mathrm{~cm}$ ). (f) Biofilm is dominated by cyanobacteria and upon reaction with dilute acid, bubbles of $\mathrm{CO}_{2}$ become visible under light microscopy. (g) Drainage channel for the TSF at Mount Keith with (h) floating microbial mats (marker for scale). (i) Light micrograph of microbial mat with tailings grains and small bubbles of $\mathrm{CO}_{2}$ produced from reaction with dilute acid indicating an association with carbonate minerals.
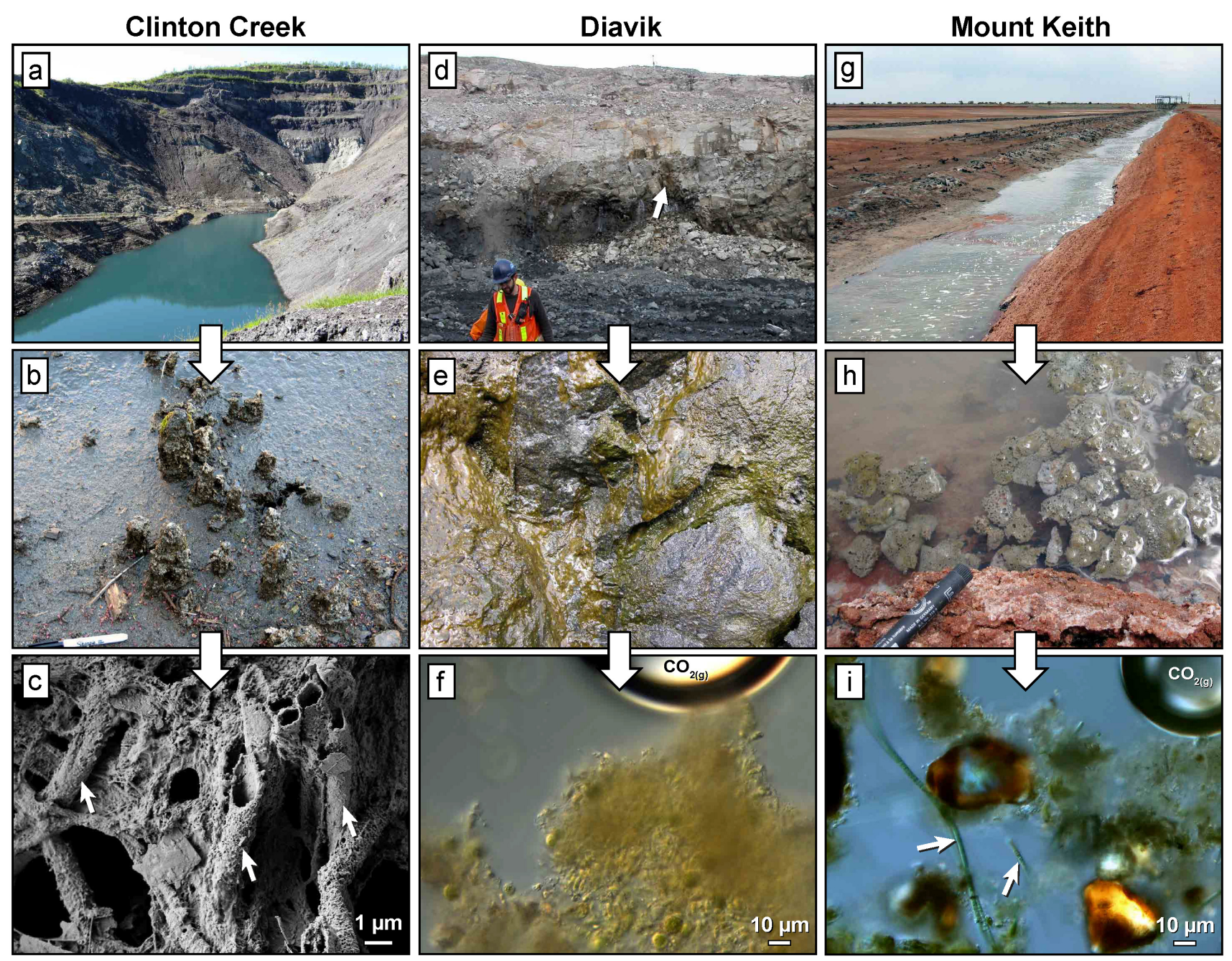
Table 2. Summary of accelerated carbon mineralization strategies.

\begin{tabular}{|c|c|c|c|c|}
\hline Strategy & Rate-limitation targeted & Processes & Example technology & Key considerations \\
\hline Bioleaching & - Mineral dissolution & $\begin{array}{l}\text { Acid generation by oxidation } \\
\text { of sulfides/sulfur by } \\
\text { Acidithiobacillus spp. }\end{array}$ & - Heap leaching & $\begin{array}{l}\text { Availability of inexpensive } \\
\text { acid-generating substances }\end{array}$ \\
\hline $\begin{array}{l}\text { Oxidation of } \\
\text { waste organics }\end{array}$ & $\begin{array}{l}\text { - Mainly } \mathrm{CO}_{2} \text { supply and } \\
\text { mineral dissolution, also } \\
\text { carbonate precipitation }\end{array}$ & $\begin{array}{l}\text { - Heterotrophic oxidation of } \\
\text { organics for in situ supply } \\
\text { of } \mathrm{CO}_{2}\end{array}$ & $\begin{array}{l}\text { Wastewater supply to TSF } \\
\text { (e.g., Diavik and Mount } \\
\text { Keith) }\end{array}$ & $\begin{array}{l}\text { Availability, degradability, } \\
\text { and carbon content of } \\
\text { waste organics }\end{array}$ \\
\hline Bioreactors & $\begin{array}{l}\text { - } \\
\text { - } \mathrm{CO}_{2} \text { supply if incorporating } \\
\text { carbonic anhydrase }\end{array}$ & $\begin{array}{l}\text { - } \text { Microbial carbonate precipitation } \\
\text { (e.g., alkalinization) } \\
\text { - Biomass production }\end{array}$ & $\begin{array}{l}\text { Wetlands for treating mine } \\
\text { drainage } \\
\text { - Bioreactors for biofuel } \\
\text { production }\end{array}$ & $\begin{array}{l}\text { - } \text { Available resources (e.g., water) } \\
\text { - } \text { Rates of carbonate biomass } \\
\text { production } \\
\text { - } \text { Quality of biomass (e.g., } \\
\text { lipid content) }\end{array}$ \\
\hline
\end{tabular}


Figure 3. A conceptual diagram consisting of the three fundamental processes that may be rate-limiting for carbon mineralization within a TSF. Strategies for accelerating carbon mineralization target one or more potential rate limitations (modified from [35]).

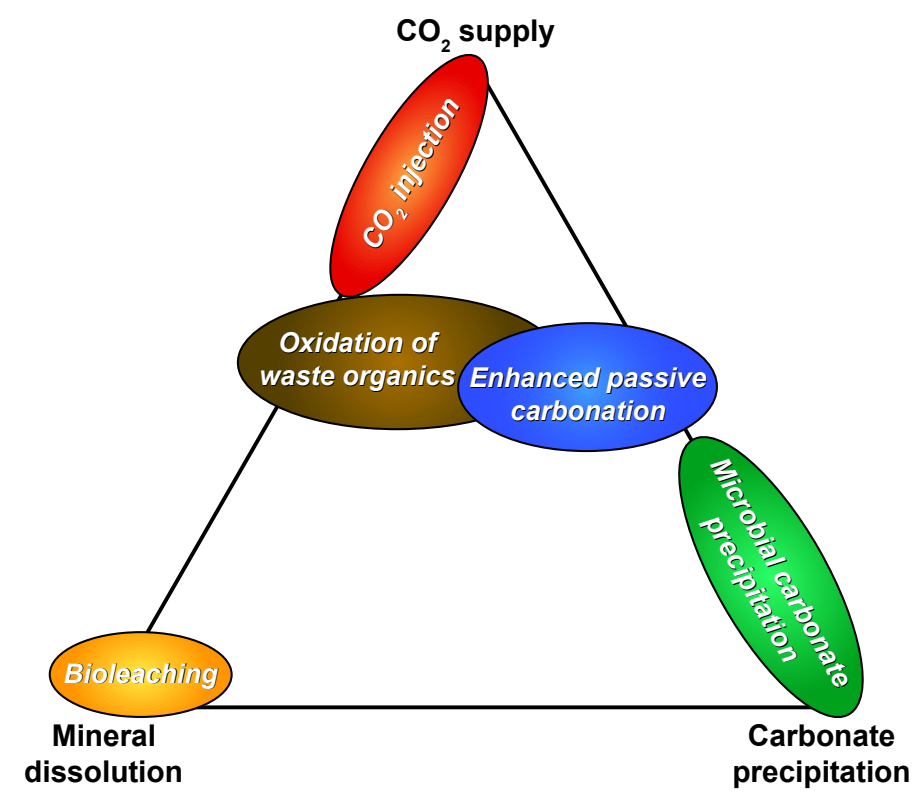

\subsection{Bioleaching of Ultramafic Mine Tailings}

The reactivity of ultramafic mine waste is enhanced by increased surface area due to mineral processing, yet dissolution rates remain sluggish at the alkaline $\mathrm{pH}$ of process waters [11,38,52-55]. Consequently, it may be advantageous to accelerate tailings mineral dissolution by altering the $\mathrm{pH}$ of process waters. The $\mathrm{pH}$-dependent dissolution rates for some common ultramafic tailings minerals such lizardite [55], chrysotile [38], forsterite [53] and brucite [54] have been experimentally determined and generally increase with increasing acidity. Several studies have demonstrated enhanced dissolution of serpentine and olivine by microbes mainly through the production of organic acids (e.g., [56-58]).

Heap leaching has been used at some mining facilities to enhance metal extraction from low-grade sulfidic ores of copper, gold, uranium and zinc [59-61]. These sulfidic materials provide an ideal habitat for acid-generating microbes (e.g., Acidithiobacillus spp.) that greatly accelerate the generation of sulfuric acid for mineral dissolution and metal leaching [62-65]. A similar process using acid-generating bacteria could be applied to TSFs with ultramafic mine tailings. Appropriate bacteria for bioleaching include Leptospirillum ferrooxidans (an iron oxidizer), Acidithiobacillus ferrooxidans (an iron and sulfur oxidizer), and A. thiooxidans (a sulfur oxidizer) [64,66]. These bacteria are chemoautotrophs meaning they obtain their energy through chemical processes and use $\mathrm{CO}_{2}$ as a carbon source, which is important for carbon sequestration. Sulfuric acid is generated through the biooxidation of sulfur-bearing minerals, containing reduced iron (Equations (2) and (3) using pyrite as an example) and elemental sulfur (Equation (4)). At low $\mathrm{pH}$ values, ferric iron catalyses pyrite oxidation resulting in considerable acid generation (Equation (3)).

$$
\begin{gathered}
4 \mathrm{Fe}^{2+}+\mathrm{O}_{2}+4 \mathrm{H}^{+} \rightarrow 4 \mathrm{Fe}^{3+}+2 \mathrm{H}_{2} \mathrm{O} \\
\mathrm{FeS}_{2}+14 \mathrm{Fe}^{3+}+8 \mathrm{H}_{2} \mathrm{O} \rightarrow 15 \mathrm{Fe}^{2+}+2 \mathrm{SO}_{4}{ }^{2-}+16 \mathrm{H}^{+}
\end{gathered}
$$




$$
2 \mathrm{~S}^{0}+3 \mathrm{O}_{2}+2 \mathrm{H}_{2} \mathrm{O} \rightarrow 2 \mathrm{SO}_{4}{ }^{2-}+4 \mathrm{H}^{+}
$$

Under acidic conditions $(\mathrm{pH}<4)$, acidophilic bacteria can generate acid at a rate of up to $10^{5}$ times faster than abiotic processes $[67,68]$.

With regard to ultramafics, bioleaching has been applied to low-grade ultramafic nickel ores containing sulfide minerals for metal recovery [69-75]. Zhen et al. [74] used a consortium of L. ferrooxidans, A. ferrooxidans, and A. thiooxidans to bioleach nickel-bearing sulfide ore from the Jinchuan mine, China. The ore contained a host of Mg-bearing minerals, dominantly olivine and antigorite as well as minor abundances of sulfide minerals, including pyrrhotite [FeS] and pentlandite $\left[(\mathrm{Fe}, \mathrm{Ni})_{9} \mathrm{~S}_{8}\right]$. Through serial culturing, the microbial consortium was able to tolerate $\mathrm{Mg}$ concentrations of up to $25 \mathrm{~g} / \mathrm{L}$. Qin et al. [73] used this consortium for bioleaching a 500-tonne heap that was irrigated by a network of pipes and drippers. Purge solution chemistry during pre-leaching had $\mathrm{Mg}$ concentrations of $45.0-55.0 \mathrm{~g} / \mathrm{L}$ and during bioleaching of $24.0-26.0 \mathrm{~g} / \mathrm{L}$. This is 10 to $10^{3}$ times the concentration of $\mathrm{Mg}$ that is available to form carbonate minerals in TSF process water at Clinton Creek, Diavik and Mount Keith (Table 1).

In the case of ultramafic tailings in many TSFs, including those at Clinton Creek, Diavik and Mount Keith, there may be insufficient energy sources (e.g., sulfide minerals) to support acid-generating microbes. A potential strategy for cultivating these microbes in TSFs involves amending tailings with an acid-generating substance, such as waste sulfides or elemental sulfur [13]. Using Clinton Creek chrysotile tailings, either waste sulfides or elemental sulfur were layered onto tailings (Figure 4a) in column experiments to support viable populations of $A$. ferrooxidans (avg. $=1.5 \times 10^{7}$ cells $/ \mathrm{g}$ ) and A. thiooxidans (avg. $=1.6 \times 10^{8}$ cells $/ \mathrm{g}$ ), respectively. Greater microbial populations and quantities of acid-generating substances resulted in greater leachate $\mathrm{Mg}$ concentrations. In comparison to controls lacking microbes, leachate waters from biotic columns with ground pyrite had $\mathrm{Mg}$ concentrations that were up to $26 \%$ greater, and in columns using elemental sulfur $\mathrm{Mg}$ concentrations were up to $580 \%$ greater (Figure 5b) [13]. There was good agreement between the experimental results and those predicted using a $\mathrm{pH}$-dependent chrysotile dissolution rate law [38], hence geochemical modeling could be used in a predictive capacity. In year-long trials (Figure $4 \mathrm{c}, \mathrm{d}$ ), $10 \%$ to $14 \%$ of the $\mathrm{Mg}$ contained within chrysotile was leached from the columns using acid-generating substances colonized by Acidithiobacillus spp. [13]. Acid-generating substances were typically at $\mathrm{pH} \sim 2$, whereas leachate solutions were $\mathrm{pH} \sim 8.5$, as reaction with chrysotile neutralized acidity. $\mathrm{Mg}$ concentrations in leachates generated by those columns containing metal sulfides generally declined over the year, likely owing to the passivation of chrysotile surfaces by iron hydroxides [13], whereas $\mathrm{Mg}$ concentrations generally increased in columns using elemental sulfur, possibly owing to increasing populations of A. thiooxidans. In short, an addition of an acid-generating substance colonized by Acidithiobacillus spp. could significantly enhance the release of $\mathrm{Mg}$ ions by nearly two orders of magnitude with minimal intervention once the process was initiated.

A key consideration with bioleaching is to prevent the drainage of acidic waters (Table 2). Acid-base accounting is used for predicating the potential onset of acid mine drainage [76]. These same procedures could be applied to a bioleaching scenario to ensure that the neutralization potential of tailings is not exceeded [13]. The quantity of acid-generating material can be adjusted to maximize mineral dissolution, yet prevent acidic drainage. 
Figure 4. Bioleaching of ultramafic mine tailings (after Power et al. [13]). (a) Schematic of a bioleaching column using an acid-generating substance colonized by Acidithiobacillus spp. for accelerating dissolution of Clinton Creek chrysotile tailings. (b) Average $\mathrm{Mg}$ concentration of leachate from one-month column experiments with comparison to abiotic controls and a control lacking pyrite and sulfur. (c,d) Plots of $\mathrm{Mg}$ (triangles) and $\mathrm{Si}$ (diamonds) concentrations versus time from year-long trials. $\mathrm{pH}$ of the sulfidic tailings and elemental sulfur (dashed lines) and the leachate solutions (solid lines) are also plotted.

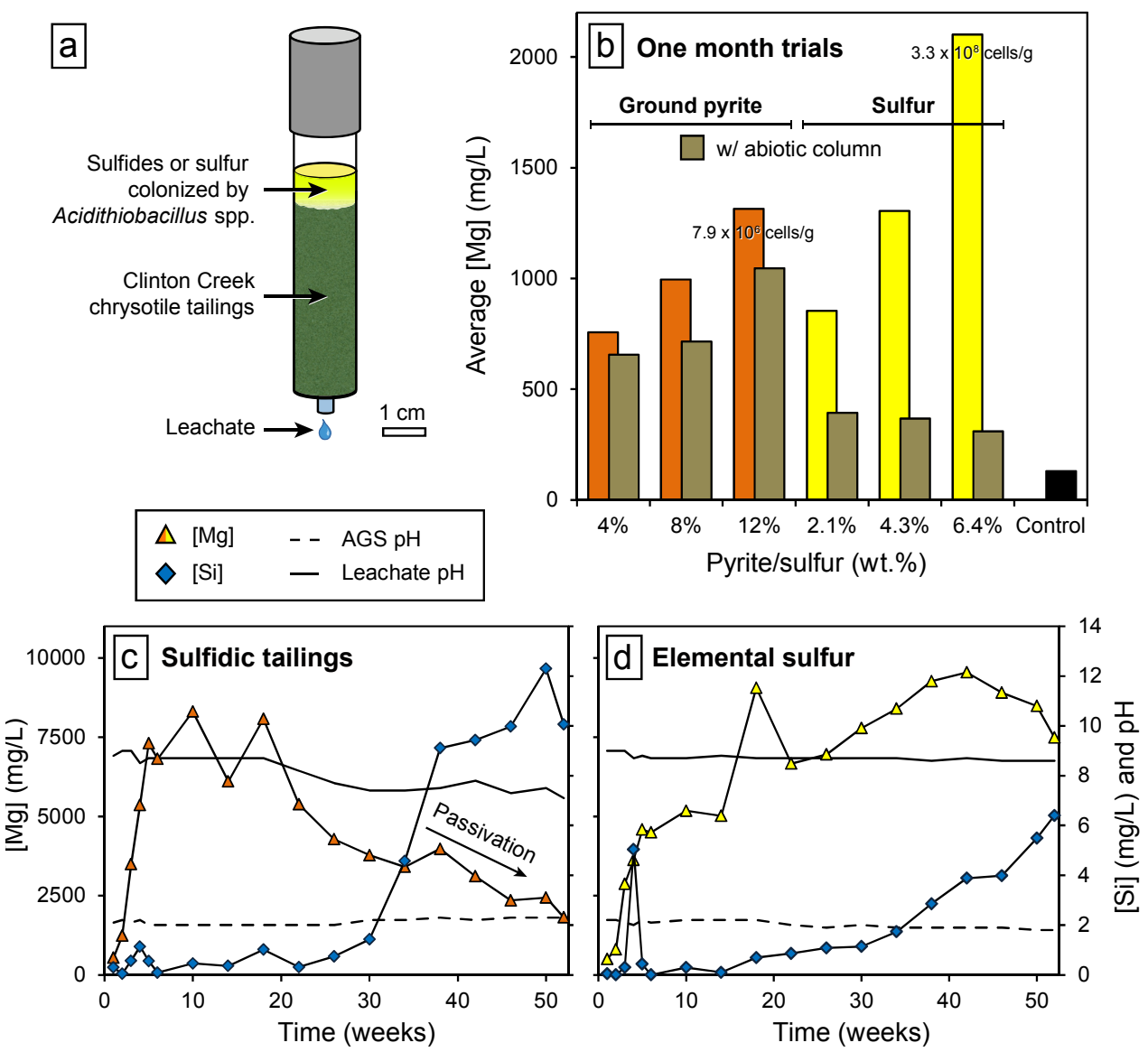

\subsection{Increasing the Supply of $\mathrm{CO}_{2}$}

Stable carbon and oxygen isotopic compositions of hydrated $\mathrm{Mg}$-carbonate minerals formed from weathering of ultramafic mine tailings at Diavik [17], Mount Keith [16], and other ultramafic-hosted mines in Norway [26] are consistent with carbon mineralization under $\mathrm{CO}_{2}$ limited conditions. In addition, $\mathrm{CO}_{2}$-depleted air has been documented to vent from chrysotile mining waste, further suggesting the $\mathrm{CO}_{2}$ supply may be limiting for carbon mineralization [24]. This is likely due to the relatively slow gas to solution transfer and hydration of $\mathrm{CO}_{2(\mathrm{aq})}$ [77], and the limited ingress of atmospheric $\mathrm{CO}_{2}$ into tailings [19]. Here, we review both potential abiotic and biotic strategies for increasing the supply of $\mathrm{CO}_{2}$ in a TSF.

\subsubsection{Enhanced Passive Carbonation}

Altering tailing deposition practices could significantly increase rates of passive carbonation by increasing the exposure of tailings to atmospheric $\mathrm{CO}_{2}$ [19]. Upon deposition, tailings are at or near the 
surface and thus are subject to weathering while they are exposed to meteoric or process water and atmospheric $\mathrm{CO}_{2}$. As tailings are buried or immersed in TSF ponds, they receive less exposure to $\mathrm{CO}_{2}$, which inhibits passive carbonation. Assima et al. [23] recommend an engineered design for efficient hydrodynamic conditions that would improve carbonation of chrysotile mining residues. Tailings management would aim to facilitate drainage and diffusion of $\mathrm{CO}_{2}$. Wilson et al. [19] proposed that the rate of passive carbonation at Mount Keith could be enhanced by altering overall tailings deposition rates. Increasing the number of deposition points or increasing the areal footprint of the TSF would better control the thickness of tailings deposits and, hence, increase duration of exposure to atmospheric $\mathrm{CO}_{2}$. Collectively we refer to these strategies as "enhanced passive carbonation" because the intended purpose of these human mediations is to enhance carbonation that occurs passively under normal mining conditions. Carbonation could be further enhanced by circulation of air throughout tailings piles to increase the exposure of reactive phases to $\mathrm{CO}_{2}$ [19]. This is similar to existing technologies for in situ aeration (i.e., air sparging), an established method for bioremediation of contaminated groundwater where increased $\mathrm{O}_{2}$ concentrations stimulate growth of aerobic heterotrophs (e.g., $[78,79]$ ).

Some considerations for enhanced passive carbonation are the abundance of highly reactive phases (e.g., oxides and hydroxides) that react more readily with atmospheric $\mathrm{CO}_{2}$, the availability of land to increase the areal footprint of a TSF, the permeability of tailings, the climate, and the economic viability of deploying the required infrastructure (Table 2).

\subsection{2. $\mathrm{CO}_{2}$ Injection}

Injection of $\mathrm{CO}_{2}$-rich gases or fluids directly into ultramafic tailings has been proposed for accelerating carbon mineralization [28]. This would significantly increase the supply of $\mathrm{CO}_{2}$ that could then be mineralized by either abiotic or microbial means. Direct carbonation of mine tailings requires both mineral dissolution and carbonate precipitation to occur simultaneously. Mineral buffering under high $p \mathrm{CO}_{2}$ conditions can be sufficient to maintain circumneutral $\mathrm{pH}$ at conditions that may also allow for carbonate precipitation [28]. The carbonation of brucite, a highly reactive tailings mineral, can be accelerated by up to $\sim 240$ times over passive rates by supplying gas streams with $\mathrm{CO}_{2}$ contents similar to power plant flue gas $\left(10 \%-20 \% \mathrm{CO}_{2}\right)$ [28]. The supply of $\mathrm{CO}_{2}$-rich gas streams not only accelerates brucite carbonation by providing more $\mathrm{CO}_{2}$, but also by increasing the $\mathrm{HCO}_{3}{ }^{-}$concentration of solutions, which interacts with the brucite surface and promotes dissolution [80]. Dissolution rates of some silicate minerals such as lizardite may also be modestly increased in the presence of $\mathrm{HCO}_{3}{ }^{-}$ (e.g., [55]). This strategy is dependent on the availability of a $\mathrm{CO}_{2}$ point source, such as might be provided by an on-site power plant ([81] and references therein). Injection of $\mathrm{CO}_{2}$ would likely shift the overall carbon mineralization rate from being $\mathrm{CO}_{2}$ limited to $\mathrm{Mg}$-limited [40]. Injection of $\mathrm{CO}_{2}$ into the subsurface, such as in saline aquifers, is currently being practiced (e.g., $[82,83])$ and there are pilot projects (e.g., CarbFix) for injecting $\mathrm{CO}_{2}$ into mafic rocks [84,85]. These technologies could be adapted for injection into ultramafic mine tailings. An important consideration for $\mathrm{CO}_{2}$ injection strategies is the proximity of the $\mathrm{CO}_{2}$ point source to the TSF, as transport of $\mathrm{CO}_{2}$ is costly (Table 2). The effective permeability of tailings should also be considered, as high injection pressures may be required to maintain a $\mathrm{CO}_{2}$ flux through low permeability media, leading to higher operating costs [19]. 
Additionally, in situ carbonation may also lead to passivation of reactive surface areas and changes in permeability [86].

\subsubsection{Oxidation of Waste Organics}

Numerous studies have documented biologically induced carbonate precipitation by heterotrophic bacteria, including sulfate reducers, which use organics as a carbon source [87-90]. Waste organics could act as a $\mathrm{CO}_{2}$ source given that heterotrophic bacteria may completely oxidize organic compounds to produce $\mathrm{CO}_{2}$, which if not mineralized, will likely be released to the atmosphere (Equation (5)).

$$
\mathrm{C}_{6} \mathrm{H}_{12} \mathrm{O}_{6}+6 \mathrm{O}_{2} \rightarrow 6 \mathrm{CO}_{2}+6 \mathrm{H}_{2} \mathrm{O}
$$

Mine camp sewage at Diavik and Mount Keith are ultimately fed to their TSFs for disposal. At Diavik, aerobic oxidation of organic matter produces $\mathrm{CO}_{2}$ that may become incorporated into secondary carbonate minerals [17]. Given the small volume of treated sewage directed to the TSF, this is a relatively minor source of carbon (Table 1). Additional waste organics would be required to significantly increase carbon mineralization. For example, Mitchell et al. [91] suggest that municipal wastewater ( $\sim 20 \mathrm{~g}$ urea/L) could be injected into the subsurface where bacterial ureolysis would generate alkalinity thereby inducing $\mathrm{Ca}$-carbonate precipitation and fixing $\mathrm{CO}_{2}$. Lindsay et al. [92,93] proposed amending mine tailings with waste organics for preventing the release of toxic metals through enhancing in situ microbial sulfate reduction. Use of peat, spent brewing grain, and municipal biosolids generated alkalinities of $\sim 1000-2000 \mathrm{mg} \mathrm{CaCO}_{3} / \mathrm{L}$ with $\delta^{13} \mathrm{C}$ values $(<-20 \%$ ) indicating that dissolved inorganic carbon (DIC) was supplied by oxidation of organics [92,93]. Biosolids may also be used for stabilizing and revegetating mine tailings [94-96]. In addition, leaching of Mount Keith and Diavik tailings using acetic acid has been shown to produce Mg-acetate solutions that foster considerable precipitation of dypingite when inoculated with a consortium of cyanobacteria and heterotrophic bacteria [15]. Heterotrophic metabolism, nitrification, and anaerobic fermentation may generate organic acids that promote mineral dissolution, whereas alkalinity generating processes such as denitrification and methanogenesis may induce carbonate precipitation [32,97]. When considering the use of waste organics, the quantity of available carbon and the biodegradability of the waste should be considered (Table 2). An abundant, easily accessible and degradable waste with high carbon content is likely to maximize $\mathrm{CO}_{2}$ supply.

\subsection{Bioreactors for Carbon Mineralization}

In nature, silicate dissolution is often biogeochemically coupled to the precipitation of carbonate minerals by microorganisms [98]. A wide range of microbial metabolisms may induce carbonate precipitation under suitable geochemical conditions [98-101]. Alteration of water chemistry through microbial metabolism may occur within the microenvironment surrounding a cell, within the interstitial water of a biofilm or microbial mat, or at a larger scale, such as a body of water. If a suitable habitat and favorable geochemical conditions were provided, microbial carbonate precipitation could operate in a TSF for the purpose of carbon sequestration. Relevant reviews of microbially induced carbonate precipitation are provided by Riding [102], Dupraz et al. [101], Jansson and Northen [103], and Kamennaya et al. [104]. 
Photosynthesis as a biological pathway for carbon mineralization is advantageous as $\mathrm{CO}_{2}$ is used by microbes as a carbon source (e.g., [104]). Photoautotrophs possess carbon-concentrating mechanisms that enable them to increase the concentration of $\mathrm{CO}_{2}$ inside their cells to as much as three orders of magnitude greater than in the extracellular environment $[105,106]$. DIC is transported into the cell and converted to $\mathrm{HCO}_{3}{ }^{-}$by the enzyme, carbonic anhydrase (CA). $\mathrm{HCO}_{3}{ }^{-}$anions enter the carboxysome via diffusion, at which point they are converted to $\mathrm{CO}_{2}$ by $\mathrm{CA}$ and subsequently into biomass (Equation (6)) [102]. This process generates $\mathrm{OH}^{-}$ions and results in a $\mathrm{pH}$ increase (e.g., alkalinization) in the cell's microenvironment that can induce carbonate precipitation in geochemical environments that have sufficient cation and DIC concentrations [107] (Equation (6)).

$$
\mathrm{HCO}_{3}{ }^{-}+\mathrm{H}_{2} \mathrm{O}+h v \rightarrow \mathrm{CH}_{2} \mathrm{O}+\mathrm{OH}^{-}+\mathrm{O}_{2} \uparrow
$$

Photoautotrophs may also induce carbonate precipitation by the adsorption of cations onto their cell walls, thereby increasing cation concentrations in the microenvironment [108-110]. Cell walls often have a net-negative charge because of the presence of functional groups such as carboxyl groups. In addition, extracellular polymeric substances (EPS) produced by cells, typically contain "excess" negatively charged functional groups [101]. Cations adsorbed to functional groups may become partially dehydrated, allowing for carbonate ions $\left(\mathrm{CO}_{3}{ }^{2-}\right)$ to react with the otherwise inaccessible cations (Equation (7)) [111-113].

$$
\text { R.COO }{ }^{-}+\left[\mathrm{Mg}\left(\mathrm{H}_{2} \mathrm{O}\right)_{6}\right]^{2+} \rightarrow\left[\mathrm{Mg}\left(\mathrm{H}_{2} \mathrm{O}\right)_{5}(\mathrm{R} . \mathrm{COO})\right]^{+}
$$

This is particularly important in the case of $\mathrm{Mg}^{2+}$ because it is usually bound in an octahedrally-coordinated inner hydration shell of six water molecules, and the exchange rate of water molecules in this shell is much slower than other cations such as $\mathrm{Ca}^{2+}$ [114-117]. An alternative precipitation mechanism involves intracellular precipitation of amorphous carbonates, as demonstrated by a recently discovered cyanobacterial species of the order Gloeobacterales [118]. This could offer another biological pathway for $\mathrm{CO}_{2}$ sequestration as these cyanobacteria may exert greater control over carbonate precipitation.

Experimental studies by Power et al. [51] and Shirokova et al. [119] have demonstrated cyanobacterially-mediated precipitation of $\mathrm{Mg}$-carbonate minerals from $\mathrm{Mg}-\mathrm{HCO}_{3}$ waters. In previously unreported results, the consortium used by Power et al. [51] was able to induce carbonate precipitation in experiments using water sourced from the open pit at Clinton Creek. After six weeks of incubation, $\mathrm{pH}$ had increased from 8.4 to 9.2 and $\mathrm{Mg}$ concentration had decreased from 356 to $278 \mathrm{mg} / \mathrm{L}$, whereas the $\mathrm{pH}$ of the control remained constant and $\mathrm{Mg}$ concentration increased to $401 \mathrm{mg} / \mathrm{L}$ due to evapoconcentration. SEM imaging revealed that a fine-grained carbonate mineral had precipitated within the biofilm of filamentous cyanobacteria (Figure 5a). In another study, unicellular green algae (cf. Dunaliella sp.) induced carbonate precipitation from waters produced by leaching of Diavik and Mount Keith tailings using various acids [15]. Abundant carbonate precipitation occurred in systems that had used acetic acid for leaching, which provided an additional carbon source (Figure 5b,c). In contrast, $\mathrm{Mg}$ - and Ca-silicate minerals coated cell surfaces (Figure 5d) in systems that relied on atmospheric $\mathrm{CO}_{2}$ as the sole source of carbon, indicating that $\mathrm{CO}_{2}$ supply from the atmosphere was rate-limiting for carbon mineralization. Consequently, additional carbon sources or more proficient means of delivering atmospheric $\mathrm{CO}_{2}$ into solution are required to accelerate microbial carbonate precipitation. 
Figure 5. Representative scanning electron micrographs from carbonate precipitation experiments showing microbe-mineral interactions. (a) Fine-grained carbonate precipitates (arrows) formed in association with filamentous cyanobacteria in experiments using water from the open pit pond at Clinton Creek. (b) Algal cells (arrows) on the surface of Ca-carbonate aggregate and (c) filamentous cyanobacteria on a large $(\sim 10 \mu \mathrm{m}$ wide) rosette of dypingite (bottom right). Solutions produced by leaching of Diavik (b) and Mount Keith (c) tailings using acetic acid, which acted as an additional carbon source. (d) Algal cell completely encrusted by fine-grained $\mathrm{Mg}$-Ca-silicates from solutions produced by leaching of Mount Keith tailings [15].
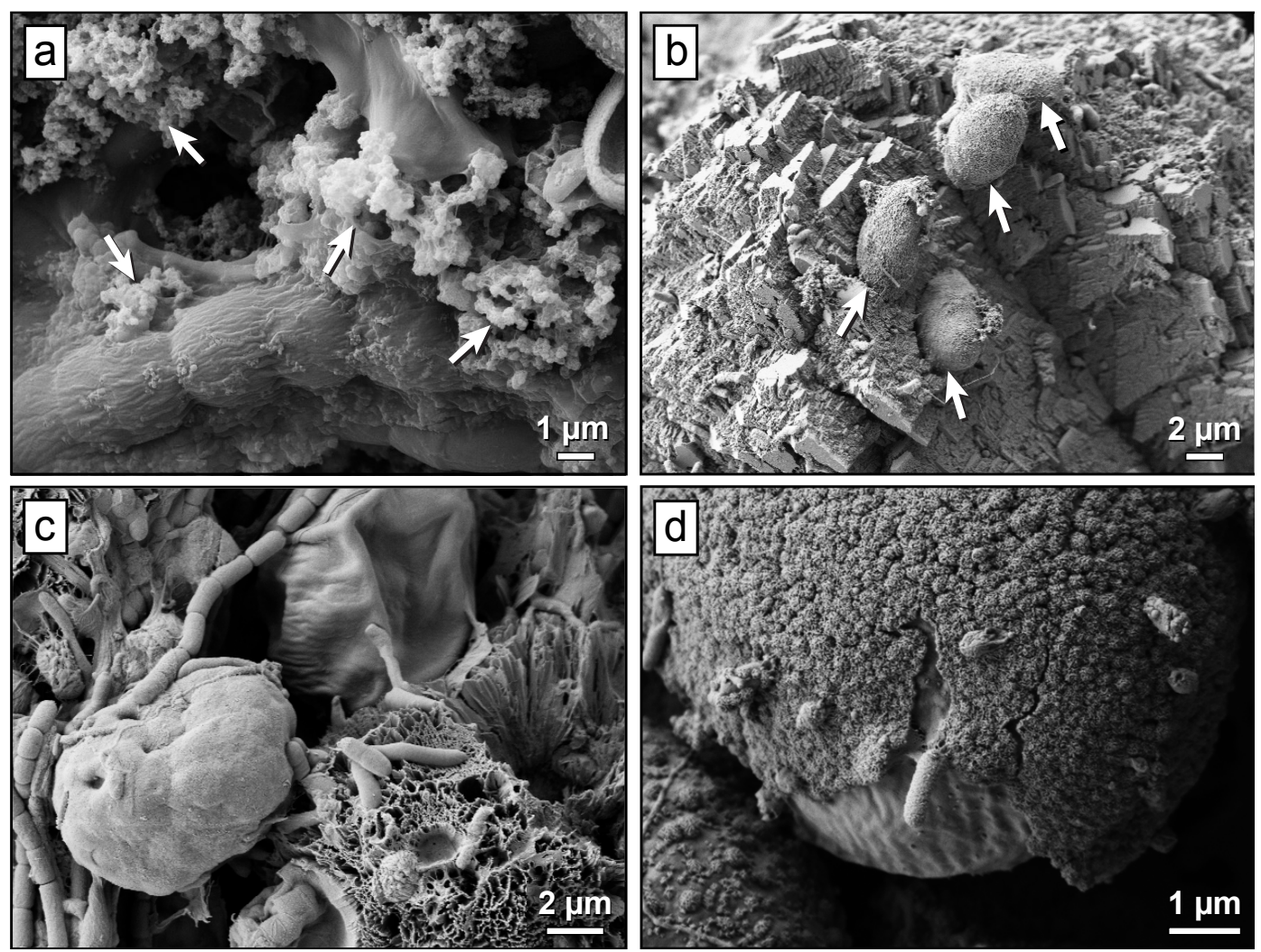

In the presence of elevated $\mathrm{CO}_{2}$ concentrations, some species of cyanobacteria and microalgae experience an increase in growth rate, photosynthetic activity, and nitrogen fixation [120-125]. Greater microbial growth rates would result in an increased availability of the EPS-hosted reactive groups needed for cation concentration and dehydration. Increased levels of $\mathrm{CO}_{2}$, which could be achieved within a TSF carbonation pond by bubbling concentrated $\mathrm{CO}_{2}$ into the water, would stimulate biological activity while also providing increased availability of DIC for carbonate precipitation. For instance, in a raceway pond experiment Chlorella sp. and Spirulina platensis achieved 46\% and 39\% mean $\mathrm{CO}_{2}$ fixation efficiency using an input $\mathrm{CO}_{2}$ concentration of $10 \%$, which is similar to the composition of flue gas [126]. An alternative means of increasing $\mathrm{CO}_{2}$ supply involves the direct use of $\mathrm{CA}$, which catalyzes the hydration of aqueous $\mathrm{CO}_{2}$, for carbon mineralization. $\mathrm{CA}$ is produced by prokaryotes and eukaryotes and is actively being investigated as an additive for accelerating carbonate precipitation, typically as part of an industrial process [39,127-131]. A challenge associated with elevated $\mathrm{CO}_{2}$ concentrations is that dissolving $\mathrm{CO}_{2}$ into water decreases $\mathrm{pH}$, and therefore decreases carbonate mineral saturation. 
Photoautotrophic carbonate precipitation could be encouraged in bioreactors or open ponds "downstream" of a TSF such that the pond receives tailings process waters rich in cations [15]. Wetlands used for treating acid mine drainage [132,133] and bioreactors for biofuel production [134] are technologies that could be adapted for developing bioreactors for carbon mineralization. The global abundance of salt tolerant cyanobacteria make them a favorable target for growth in saline mine process waters. Organic-rich wastewater from mining camps would offer an inexpensive source of nutrients (e.g., nitrogen and phosphorous) for growth of phototrophs (Table 1). In addition to economic considerations, space and water required for cultivating microalgae and cyanobacteria must be considered (Table 2). There is potential to extend the industrial use of photoautotrophs by using the generated biomass for producing biofuels and other valuable by-products [134-136]. Few studies have investigated coupling of microbial carbonate formation with biomass production for the purpose of sequestering $\mathrm{CO}_{2}[15,126,137]$.

\section{A Case for Pilot Projects}

Individual mines generate considerable amounts of GHGs from point sources, mainly from fossil fuel consumption for power generation, and distributed sources such as those from trucks and mining equipment. Protocols exist for mining operations to estimate their GHG emissions from fuel combustion and specific process-related activities (e.g., [138]). For instance, the Mount Keith nickel mine emitted $\sim 382 \mathrm{kt}$ of $\mathrm{CO}_{2} \mathrm{e}$ in 2004 [36]. Comminution ( 53\%), flotation $(\sim 13 \%)$, and mining equipment $(\sim 34 \%)$ are key contributors to GHG emissions [139]. Point sources at mine sites offer a potential $\mathrm{CO}_{2}$ supply for carbon mineralization, whereas, distributed sources can be offset either by direct capture from the atmosphere or by utilizing additional offsite $\mathrm{CO}_{2}$ sources. At Mount Keith, the $11 \mathrm{Mt}$ of tailings generated each year would sequester $3400 \mathrm{kt} \mathrm{CO} /$ year and $170 \mathrm{kt} \mathrm{CO}_{2} /$ year from complete carbonation of antigorite + lizardite and brucite, respectively to form hydromagnesite, which in total would offset mine emissions by approximately 10 times (Table 1). Prior to the construction of the centralized TSF at Mount Keith, field trials were conducted to develop better approaches to tailings storage. These trials consisted of six storage units $(25 \times 25 \mathrm{~m})$ used to establish a range parameters including settling, consolidation and drying characteristics [140]. Pilot projects of a similar scale are crucially needed in order to assess the efficacy of strategies for accelerating carbon mineralization.

In this review, we have considered five strategies for accelerating carbon mineralization in TSFs: (1) bioleaching, (2) enhanced passive carbonation, (3) $\mathrm{CO}_{2}$ injection into tailings, (4) oxidation of waste organics, and (5) bioreactors for carbon mineralization. Each of these strategies aims to minimize one or more of the potential rate limitations for carbon mineralization (Figure 3). These strategies may be modified or combined; for instance, combining the use of a bioreactor with elevated $p \mathrm{CO}_{2}$ supplied by a point source. Naturally, there are advantages and disadvantages to each strategy, which may or may not be alleviated by the use of two or more complementary strategies.

A decision tree (Figure 6) is useful for outlining beneficial combinations of strategies that may be considered for pilot projects aimed at accelerating carbon mineralization within a TSF. Carbon mineralization strategies are best employed at mine sites that will generate $\mathrm{Mg}$ - and Ca-rich mine tailings. The overall design of a carbon mineralization pilot project within a TSF will depend on a number of site-specific factors. Key considerations include the availability of a point source of $\mathrm{CO}_{2}$ 
(e.g., using $\mathrm{CO}_{2}$ from flue gas) and the abundance of highly reactive phases. In addition, there are specific considerations for each strategy discussed in this review (Table 2). For example, an inexpensive source of an acid-generating substance (e.g., sulfidic tailings or waste sulfur) would need to be available for bioleaching. Climate has an overarching influence; a warm and wet climate will encourage microbial growth, whereas warm and dry climates will increase evapoconcentration of solutes. The local climate for some mine sites, such as Diavik in the Canadian subarctic, will present challenges to both abiotic and microbially mediated carbon mineralization. Here, we consider two of the numerous possible scenarios for the design of pilot projects based on the decision tree in Figure 6 . The discussion of each scenario is based on knowledge and data gathered from the Mount Keith nickel mine (Table 1), the most thoroughly studied of the sites highlighted in this review.

Figure 6. Decision tree for developing a pilot project for accelerating carbon mineralization in mine tailings.

\section{Decision tree for design of a pilot project}

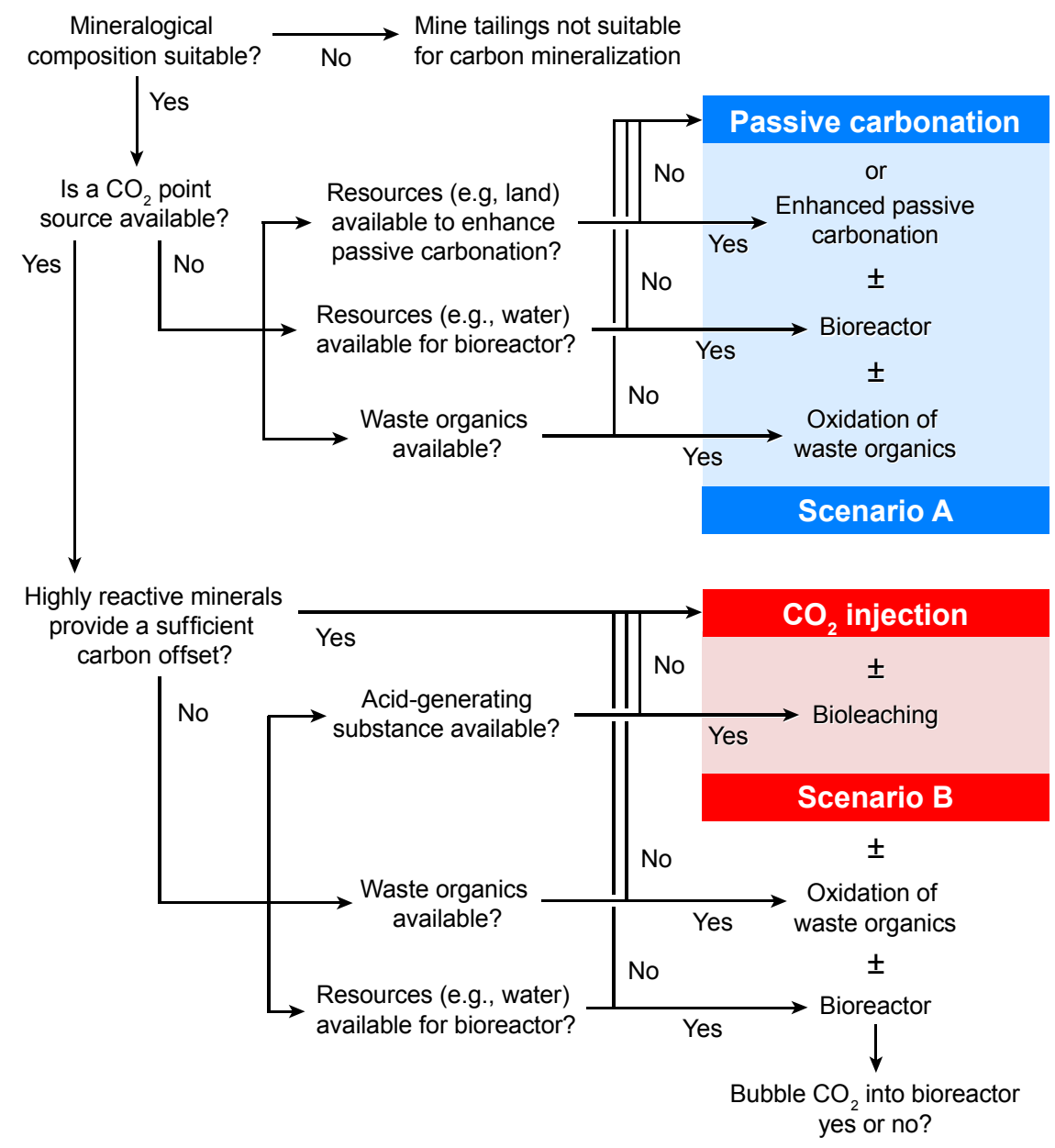

\subsection{Scenario A}

The pilot project described by Scenario A does not rely upon point sources of concentrated $\mathrm{CO}_{2}$ (Figure 6). Carbon mineralization could be accelerated by enhanced passive carbonation, use of a bioreactor, and use waste organics as an additional $\mathrm{CO}_{2}$ source. These three strategies are mutually compatible, i.e., a TSF could be designed to use any combination of these three strategies. 
Mount Keith has the greatest passive carbonation rates amongst the mines discussed in this review (Table 1). Factors facilitating carbonation at Mount Keith include the tailings mineralogy (81 wt \% lizardite + antigorite and $2.5 \mathrm{wt} \%$ brucite), the large areal footprint $\left(16.6 \mathrm{~km}^{2}\right)$ of the TSF, which, distributes tailings widely and allows for exposure to the atmosphere, a hot and dry climate with high evaporation rates, and the use of cation-rich bore water for tailings deposition [11,19,141]. The majority of hydromagnesite precipitation at Mount Keith results from reaction of brucite with dissolved atmospheric $\mathrm{CO}_{2}$ near the surface of the TSF ( $<25 \mathrm{~cm}$ depth) [19]. Consequently, passive carbonation is in part controlled by the overall tailings deposition rate $(\sim 50 \mathrm{~cm} / \mathrm{year})$, where the duration of exposure to the atmosphere is significantly reduced by frequent deposition of fresh tailings [19,40]. Tailings deposition occurs from nine risers near the center of the TSF, which restricts most tailings deposition to a smaller, centralized area rather than ensuring even distribution over the entire area of the TSF. More even spatial distribution of tailings would result in longer atmospheric exposure times, allowing a greater extent of brucite reaction [19]. A pilot project could be used to determine the deposition rates for achieving optimal carbonation of brucite present in the tailings. Enhanced passive carbonation of an average brucite abundance of $2.5 \mathrm{wt} \%$ would sequester $166 \mathrm{kt} \mathrm{CO}_{2} /$ year or $44 \%$ of mine emissions in the form of hydromagnesite. The presence of hydrotalcite group minerals $(5.8 \mathrm{wt} \%$ iowaite $\left[\mathrm{Mg}_{6} \mathrm{Fe}^{3+}{ }_{2}(\mathrm{OH})_{16} \mathrm{Cl}_{2} \cdot 4 \mathrm{H}_{2} \mathrm{O}\right]$ and 2.9 wt \% woodallite $\left.\left[\mathrm{Mg}_{6} \mathrm{Cr}_{2}(\mathrm{OH})_{16} \mathrm{Cl}_{2} \cdot 4 \mathrm{H}_{2} \mathrm{O}\right]\right)$ may offer additional $\mathrm{CO}_{2}$ storage capacity, although the extent to which these minerals could sequester $\mathrm{CO}_{2}$ has not been fully assessed [12]. Additionally, it is not known to what extent Mg-silicate minerals are contributing dissolved $\mathrm{Mg}$ to carbon mineralization at Mount Keith; however, petrographic and mineralogical evidence from this and other mines indicates that serpentine and olivine minerals can be a major source of $\mathrm{Mg}$. A pilot project could assess the contributions of hydrotalcite group minerals and $\mathrm{Mg}$-silicates to carbon sequestration under field conditions.

A greenhouse-scale bioreactor has been used to demonstrate sequestration of carbon within biomass and Mg-carbonate minerals [33]. It is important to consider that the capacity for microbially mediated carbonate precipitation to sequester $\mathrm{CO}_{2}$ is partially dependent on the volume of water available for a pond or bioreactor, whereas the rate is dependent on the microbial growth and carbonate precipitation rates that can be achieved in the presence of a given microbe, water chemistry, and climatic conditions. The Mount Keith TSF employs the natural topography of the site to collect tailings water for reuse in the ore processing circuit. A demonstration downstream bioreactor could be built at the current site of the water reclamation pond to promote simultaneous biomass production and carbon mineralization using leachate waters from the TSF. Microbial carbonate precipitation could potentially sequester $\sim 53 \mathrm{kt} \mathrm{CO}_{2} /$ year in the form of carbonate minerals with an additional $\sim 11 \mathrm{kt} \mathrm{CO}_{2} /$ year stored as biomass [15], which, in total, would offset GHG emissions by 17\%. The estimate for annual biomass production assumes a conservative growth rate of $\sim 35 \mathrm{mg}$ dry biomass/L water/day under non-ideal conditions and a lipid content of $11 \%$. Photoautotrophs could, however, represent a much more significant sink for carbon given that the median rate of biomass production for microalgae is $\sim 200 \mathrm{mg}$ dry biomass/L water/day and $\sim 24 \%$ lipid content (determined from a review by Mata et al. [134]). At these rates, GHG emissions at Mount Keith could be offset by approximately $30 \%$.

In total, Mount Keith uses approximately $11 \mathrm{GL}$ of saline water each year [36]. The mine camp produces $\sim 186 \mathrm{ML}$ of wastewater each year, which is treated and discharged into the TSF. Typical wastewater contains $100 \mathrm{~s}$ of $\mathrm{mg} / \mathrm{L}$ of dissolved organic carbon [142], which is an insignificant carbon 
source for offsetting GHG emissions. The nearest city is Kalgoorlie (population $\approx 30,000$ ), which is approximately $500 \mathrm{~km}$ south. Thus, there is no known source of additional, readily available waste organics. Nevertheless, field trials could assess the potential for mineralizing carbon from waste organics to test the extent to which this carbon may become mineralized.

\subsection{Scenario B}

Scenario $\mathrm{B}$ is based on the use of a point source of $\mathrm{CO}_{2}$ such as could be supplied from an on-site power plant burning fossil fuels (Figure 6). Bioleaching could be deployed in combination with $\mathrm{CO}_{2}$ injection. The choice of $\mathrm{CO}_{2}$ injection would likely be made based on the reactivity of mine tailings with elevated $p \mathrm{CO}_{2}$. For instance, Harrison et al. [40] estimate that carbonation of approximately $3 \mathrm{wt} \%$ brucite would be sufficient to offset point source emissions at Mount Keith and that tailings with approximately $6.5 \mathrm{wt} \%$ brucite would be sufficient to render many ultramafic-hosted mines carbon-neutral. In the case of Mount Keith, which has an average brucite abundance of $\sim 2.5 \mathrm{wt} \%$, $\mathrm{CO}_{2}$ injection rates would need to be balanced with tailings deposition rates to ensure complete carbonation of brucite and thus prevent $\mathrm{CO}_{2}$ leakage. $\mathrm{CO}_{2}$ injection would likely shift the rate limitation from $\mathrm{CO}_{2}$ supply, as in the case of passive carbonation, to cation-supply limited as the dissolution rates of the abundant $\mathrm{Mg}$-silicate minerals are sluggish in comparison to highly reactive phases like brucite [40]. However, Daval et al. demonstrated that the dissolution rate of lizardite is increased by 5 times at $\mathrm{pH} 5$ in solutions equilibrated with $\mathrm{CO}_{2}$ as compared to $\mathrm{CO}_{2}$-free solutions at the same $\mathrm{pH}$ [55], suggesting that $\mathrm{CO}_{2}$ injection into ultramafic mine tailings may also increase silicate dissolution rates, thereby increasing the cation supply.

Application of the bioleaching process to the ultramafic mine tailings at Mount Keith could accelerate $\mathrm{CO}_{2}$ sequestration by increasing the cation (e.g., $\mathrm{Mg}^{2+}$ ) supply for carbonation. Bioleaching columns amended with elemental sulfur have been shown to release up to $14 \%$ of the available $\mathrm{Mg}$ in the columns with leachate concentrations of up to $\sim 9500 \mathrm{mg} / \mathrm{L}$ (Figure 4d) [13]. In addition, bioleaching of low-grade nickel ore has been estimated to produce $\mathrm{Mg}$ concentrations in excess of 25,000 mg/L [73,75]. Reaction of brucite is largely responsible for hydromagnesite precipitation at Mount Keith. As a comparison, complete dissolution of brucite ( $2.5 \mathrm{wt} \%$ of $11 \mathrm{Mt}$ tailings/year) would contribute a $\mathrm{Mg}$ concentration of approximately $15,000 \mathrm{mg} / \mathrm{L}$ when considering the volume of saline water used at Mount Keith ( $7900 \mathrm{ML}$, determined from total water usage minus high quality water usage; Table 1). Bioleaching would best be employed when there are additional carbon sources for mineralization.

$\mathrm{CO}_{2}$ from nearby offsite point sources (e.g., other industrial operations and power plants) could also be utilized at mine sites, thereby providing a greenhouse gas benefit for other industries. Capture of atmospheric $\mathrm{CO}_{2}$ can be expected to occur in parallel with mineralization of injected $\mathrm{CO}_{2}$ as a consequence of enhanced passive weathering and atmosphere-water exchange occurring within tailings. These sources could prove useful for offsetting distributed $\mathrm{CO}_{2}$ emissions from a mine.

\subsection{Monitoring and Verification}

In addition to evaluating acceleration strategies, pilot projects would provide an opportunity for rigorous testing of monitoring and verification techniques that are needed to determine the quantity of carbon that has been sequestered and the sources of $\mathrm{CO}_{2}$. Rates of passive carbonation at Clinton 
Creek, Diavik, and Mount Keith have been determined previously [17-20]. Sampling involved collection of grab samples (e.g., 50 to $500 \mathrm{~g}$ ) of tailings from the surface and at depth (e.g., augering), which are adequate for most analyses [17,19,20]. Wilson et al. [20,21] used X-ray diffraction (XRD) data with Rietveld refinement for quantitative measurement of mineral phases including the "secondary" carbonate minerals that provide a sink for atmospheric $\mathrm{CO}_{2}$ in tailings. This same approach would be effective for assessing enhanced passive carbonation in Scenario A. A combination of stable carbon and oxygen isotopic data and radiocarbon dating of carbonate minerals were then used to verify carbon sources [17,19,21]. Sampling techniques are easily upscaled as there exists detailed guidelines for obtaining representative samples for assessing environmental impacts of mine wastes (e.g., [143]), which could be adapted for determining the extent of carbon mineralization at the mine scale. In the case of bioreactors, monitoring of water chemistry can be used as a proxy for carbonate precipitation with corroborating evidence such as XRD and electron microscopy [33]. Biomass would be analyzed for its biochemical composition such as the valuable lipid content [15].

In Scenario B, bioleaching would need to be monitored through analysis of pore water chemistry, such as $\mathrm{pH}$ and $\mathrm{Mg}$ concentration, in order to assess the rate and extent of tailings dissolution [13]. Monitoring of microbial processes, such as determining the populations of acidophiles may also be necessary. Pronost et al. [24] have demonstrated the effectiveness of a bulk monitoring strategy for passive $\mathrm{CO}_{2}$ sequestration in mine tailings. Their approach combines the use of infrared imaging to monitor heat released by exothermic carbonation reactions with direct measurement of atmospheric $\mathrm{CO}_{2}$ concentrations from air vents and seeps in TSFs. Similarly, a pilot project could be instrumented to monitor the real-time progress of carbon mineralization in a $\mathrm{CO}_{2}$ injection scenario. As carbon sequestration technologies are implemented, there will be greater emphasis placed on development of protocols for accurately assigning carbon credits to industry.

\section{Estimating Operational Costs}

This review recommends a variety of strategies that may be used in combination to realize emissions offsets. The approach presented here offers tremendous flexibility in terms of the level of emissions offsets that may be achieved for a broad range of operational costs. In Figure 7, the operational costs of carbon mineralization using mine wastes are illustrated in a conceptual model modified from Hitch and Dipple [144]. There exist two broad end members, (1) passive carbonation that offers modest offsets (e.g., 11\% of annual emissions at Mount Keith in the form of hydromagnesite) at no cost increase in mine operations and (2) carbonation using industrial reactors that may achieve upwards to complete conversion (typically $\sim 80 \%$ to $100 \%$ conversion to magnesite) at a high operational cost $\left(\sim \$ 50-100 / \mathrm{CO}_{2} ;[144,145]\right)$ (Figure 7). Using EU carbon market and UK carbon floor pricing of approximately $\$ 6$ U.S./t $\mathrm{CO}_{2}$ and $\$ 28$ U.S./t $\mathrm{CO}_{2}$, respectively, as of 1 January 2014, passive carbonation at Mount Keith can be valued at approximately $\$ 250,000$ U.S./year and $\$ 1,200,000$ U.S./year, respectively. At Mount Keith, which produces $11 \mathrm{Mt}$ of tailings annually, complete carbonation of serpentine and brucite to magnesite would offset mine emissions by $\sim 1200 \%$. The strategies discussed in this review fall between these two end members.

Scenario A coupled enhanced passive carbonation, a bioreactor, and use of waste organics (Figure 7). The costs of enhancing passive carbonation (e.g., 44\% of Mount Keith emissions) mainly relate to 
infrastructure costs such as increasing the number of deposition points or areal footprint of the TSF. Thus, significant offsets could be achieved through altering tailings management practices with little additional operational costs. Enhanced passive carbonation can be valued at approximately $\$ 1,000,000$ U.S./year (European market) or $\$ 4,700,000$ U.S./year (UK carbon floor). Biomass production could offset the operational costs associated with a bioreactor used for carbon mineralization. The estimated costs of biofuel production vary from below to greatly exceeding current oil prices ( $\sim 70$ to $\$ 3,900 /$ barrel of oil) [146]. In our cost analysis of Scenario A, we have made the conservative assumption that a bioreactor would only be operated at break even taking into account current crude oil prices ( $\sim 100 /$ barrel) and the UK carbon floor price of $\$ 28 \mathrm{t} / \mathrm{CO}_{2}$. However, if biofuel production costs are less than oil prices, then a profit can be made while more permanently sequestering $\mathrm{CO}_{2}$ as carbonate. The combination of enhanced passive carbonation and use of a bioreactor could potentially offset approximately $74 \%$ of mine emissions (44\% from enhanced passive carbonation and $30 \%$ from an efficient bioreactor). Enhanced passive carbonation is limited by the quantity of highly reactive brucite present in the tailings, whereas, a bioreactor would be limited by the volume of water along with microbial growth and carbonate precipitation rates.

Scenario $\mathrm{B}$ involved $\mathrm{CO}_{2}$ injection and bioleaching. The total costs related to carbon capture and storage (CCS) via injection into subsurface pore space can be subdivided into costs associated with $\mathrm{CO}_{2}$ capture $\left(\$ 25-115 / \mathrm{t} \mathrm{CO}_{2}\right)$, transport $\left(\$ 1-8 / \mathrm{t} \mathrm{CO}_{2} / 250 \mathrm{~km}\right.$ at 5-40 $\mathrm{Mt} \mathrm{CO}_{2} /$ year$)$, and storage $\left(\$ 0.5-8 / \mathrm{t} \mathrm{CO}_{2}\right)$. These costs are provided in a report by the Intergovernmental Panel on Climate Change (IPCC) [145]. Some mines have on-site power generation, such as at Mount Keith that provides an easily accessible, inexpensive source of $\mathrm{CO}_{2}$ thereby eliminating much of the transportation costs. Capture and storage costs would be significantly reduced given that tailings are susceptible to carbonation by gas streams of $\sim 10 \%-20 \% \mathrm{CO}_{2}$ (e.g., flue gas with no purification) [28] and the very shallow depths required for $\mathrm{CO}_{2}$ injection into tailings. Assuming an on-site $\mathrm{CO}_{2}$ source without purification, we have estimated a cost of $\$ 1.5 / \mathrm{t} \mathrm{CO}_{2}$ based on the lower range of costs given in the CCS report by the IPCC [145]. Power generation accounts for approximately $66 \%$ of emissions at Mount Keith, which if sequestered would be valued at $\$ 1,100,000$ U.S./year (European market) and $\$ 6,700,000$ U.S./year (UK carbon floor) including the sequestration cost of $\$ 1.5 / \mathrm{t} \mathrm{CO}_{2}$. Stolaroff et al. [147] estimate an operating cost of $\$ 8 / \mathrm{t} \mathrm{CO}_{2}$ using heap leaching of $\mathrm{CaO}$ - and $\mathrm{MgO}$-rich industrial wastes. Power et al. [13] demonstrated that greater than $14 \%$ of the $\mathrm{Mg}$ in experimental bioleaching columns could be leached, assuming that only a year's worth of tailings were leached and that the $\mathrm{Mg}$ was carbonated to form hydromagnesite, then $480 \mathrm{kt} \mathrm{CO}_{2}$ or $124 \%$ of mine emissions could be offset. Because the amount of $\mathrm{CO}_{2}$ generated at Mount Keith is finite, carbonation of the excess $\mathrm{Mg}$ released by bioleaching would require use of offsite sources of $\mathrm{CO}_{2}$. Mines commonly operate in remote locations, therefore we have considered a conservative sequestration cost of $\$ 8.5$ based on transportation and storage costs of $\$ 8$ and $\$ 0.5 / \mathrm{t} \mathrm{CO}_{2}$, respectively, for a total cost of $\$ 16.5 / \mathrm{tCO}_{2}$ [145]. Using the European and UK carbon prices, minus the $\$ 16.5 / \mathrm{t} \mathrm{CO}_{2}$ operational cost estimate, Scenario B would produce a negative valuation of (minus) $\$ 4,000,000$ U.S./year, versus a positive valuation of $\$ 5,400,000$ U.S./year, respectively emphasizing the importance of carbon prices in implementation of carbon sequestration technologies. In using point sources of $\mathrm{CO}_{2}$, carbonation is likely to be limited by mineral dissolution, a rate-limitation that can be overcome using bioleaching. 
Figure 7. Plot illustrating emissions offset (\%) versus cost of $\mathrm{CO}_{2}$ sequestration technology $\left(\$ / \mathrm{t} \mathrm{CO}_{2}\right)$ for a mine site based on data for the Mount Keith nickel mine. Plotted are passive carbonation, Scenarios $\mathrm{A}$ and $\mathrm{B}$, and industrial carbonation along with the EU floating and UK fixed carbon prices. Any new technology is only financially viable when its cost is below the applicable carbon price.

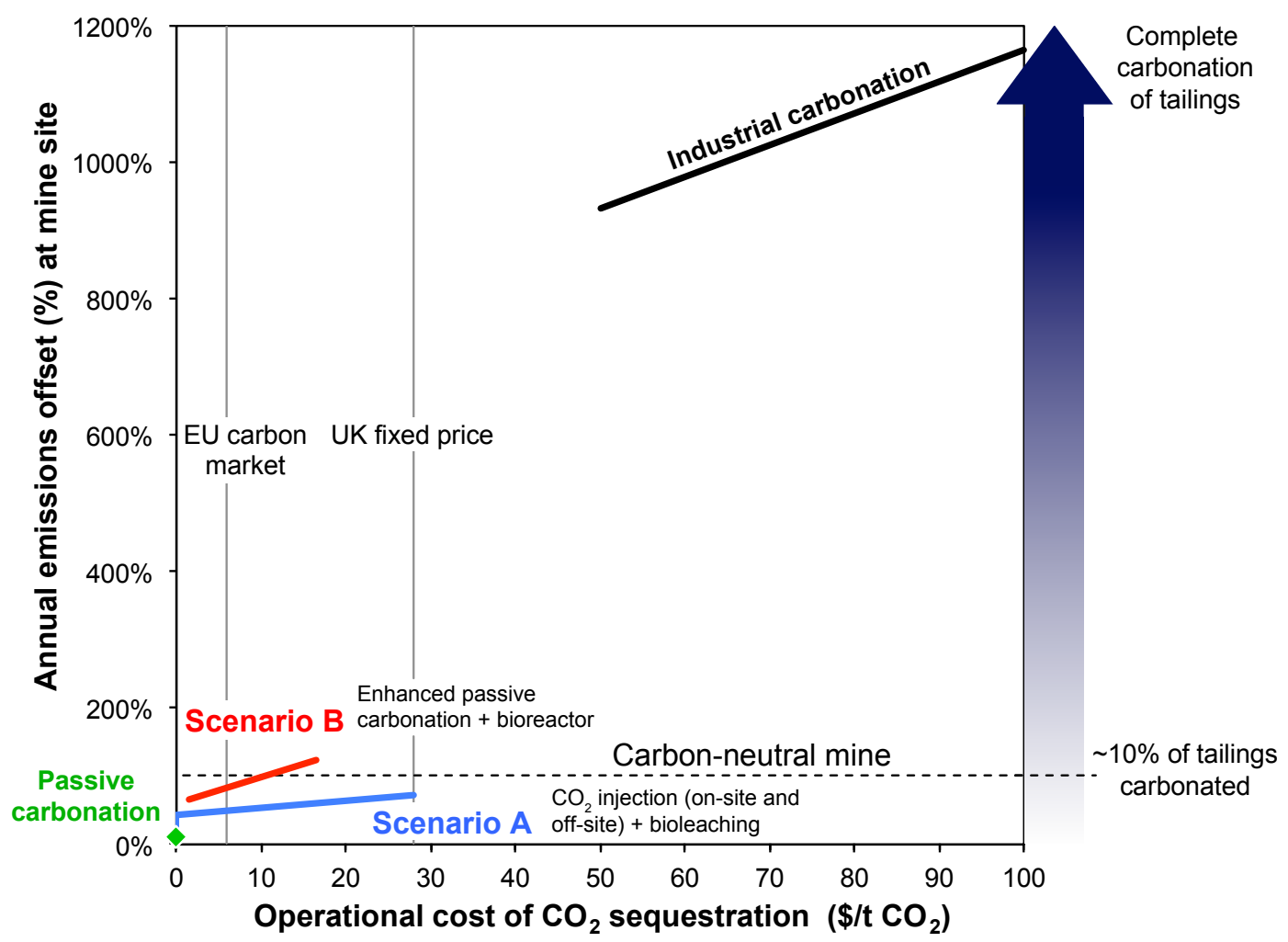

\section{Carbon Price}

It is evident that in order to assess the financial viability of the process, one must know both the amount of carbon sequestered and the carbon price. While there is no disagreement amongst economists that the true cost to society of burning one tonne of carbon is greater than its "private cost", there is no consensus about what that cost is [148]. This "social cost" of carbon (SCC) is the estimated price of the damage (unwanted climate change) caused by the increasing concentration of atmospheric GHGs; these costs are borne (at least, in part) by the world's taxpayers rather than the private cost to companies or individuals burning the GHGs. Different countries have their own policy responses to address carbon emissions: the two primary choices are a carbon market that places a 'cap' on carbon emission (but allows the market to determine the price) and a carbon tax that fixes the price of carbon (but allows the amount of carbon emissions to vary). Market-based, cap-and-trade systems are preferred and being used in India, Kazakhstan, New Zealand, Singapore, South Korea, the 31 countries covered by the EU ETS, as well as several sub-national systems in the U.S., Canada, China and Japan. The fate of existing carbon pricing policies in Australia is uncertain.

A market brings together buyers and sellers and price is determined by the forces of supply and demand; a price is simply what people are willing to pay. An issue with the market mechanism is that price is sometimes less than cost, which can lead to market failure. This is evident in the EU ETS; the per tonne EU ETS price peaked at \$38 U.S. in 2006, dropped to \$0.15 U.S. in 2007, and because of the 
global financial crisis, prices have stayed low, providing no incentive for companies to lower $\mathrm{CO}_{2}$ emissions or invest in carbon sequestration technologies. Recognition that carbon is grossly undervalued in the market came with the U.S. Interagency Working Group decision to raise its per tonne estimate of the SCC by $60 \%$ to $\$ 38$ U.S. which may be considered a "rough and politically acceptable" price floor [148]. To combat the EU ETS market failure, the UK unilaterally added a carbon tax, a floor of approximately \$28 U.S. to prop up the price of carbon. This created a "regulatory" arbitrage (i.e., an opportunity to make a riskless profit by exploiting price differences in different markets) encouraging UK firms to relocate offshore to circumvent this unfavorable "tax", essentially shifting carbon emissions out of the UK and into continental Europe.

Arbitrage exists when market prices deviate from the true values; however, it also provides a mechanism to ensure that prices do not deviate substantially from true value for long periods of time. As with all markets, this carbon market arbitrage will soon disappear as governments close the obvious loopholes in realization that a worldwide carbon solution is required to correct mispricings. Mining companies must recognize that carbon-related tax penalties and incentives are proliferating around the world and the likelihood of "escaping such changes in a global economy are becoming more remote" [149]. There is also recognition that if carbon prices do not provide an incentive for companies to reduce emissions now, then companies will be forced to do more later, at a higher cost and with greater urgency [150]. It is certain that impending international collective action will establish a global carbon price (through tax, trading or regulation) that is more closely aligned with the SCC.

\section{Valuation Model for Development of Carbon Mineralization in Mine Waste}

The carbon mineralization strategies proposed in this review could overcome previous economic challenges to carbon mineralization by using existing ultramafic mine wastes as a feedstock for an industrial (bio)technological process that occurs at ambient temperature and atmospheric pressure over decadal timescales, i.e., at rates that could become significant for GHG mitigation at mine sites. These innovations should significantly reduce the expected per tonne cost of carbon mineralization, but the widely-used net present value (NPV) approach to capital budgeting will still render these strategies economically unviable, until the market price for carbon price corrects. In making this decision, the mining company would only invest in a project if it has a positive NPV because this criterion is consistent with shareholder value maximization. Based on projections of how much future cash (S) a project will generate relative to its investment cost (X), NPV strives to calculate the value of a project today ( $\mathrm{S}-\mathrm{X}$ ). NPV uses a discounted cashflow (DCF) valuation model, which is described as "discounted" because cash in the future is worth less than cash today (referred to as the "time value of money"). We discount the future cashflows at a cost of capital (r) that reflects the rate of return that the mining company would receive if it invested in a different project with similar risk. This DCF approach can be simplified by treating carbon mineralization of mine tailings as a valuation of a limited resource with a finite life [151-154]. This finite life resource approach collapses the traditional NPV to a multiplication of the quantity of carbon fixed times the carbon price (S) less the cost of carbon capture and sequestration (X). In Section 5, this simplified approach yielded the decision not to invest in Scenario B because $\mathrm{S}-\mathrm{X}$ was negative. 
A limitation with using NPV is that it implicitly assumes that the project is held passively and that the only decision that matters is the initial decision to invest. In reality, mine managers work within a dynamic operating environment and continuously make decisions over very long time periods such as expanding, contracting, abandoning, or simply waiting for more information before acting. Dixit and Pindyck [155] showed that the NPV decision-making criterion ignores the flexibility afforded by the embedded real (i.e., non-financial) options because managers can obtain the right, but not the obligation to take a further strategic action at a future date. In a simplified financial options example, Minestock market price is $\$ 98$, the call option "premium" is $\$ 4$, "exercise price" is $\$ 100$, and the "expiration date" is 1 January which means that today, the buyer would pay $\$ 4$ (premium) to purchase the option, which would give would that person the right, but not the obligation, to purchase Minestock at the $\$ 100$ exercise price on or before 1 January (expiration date). If Minestock price rises to $\$ 120$, the buyer would be able to purchase Minestock for $\$ 100$ and sell it at the market price of $\$ 120$, making a net profit of $\$ 16$ (\$20 "profit" minus the $\$ 4$ option premium). If the stock price only reached $\$ 99$, the buyer would not exercise the option and it would simply expire. It is evident that the buyer was able to capture an unlimited upside potential in the increased stock price while limiting the downside loss to only the modest option premium. The mining company's investment in these carbon mineralization technologies should be valued using a real options approach because by making a modest investment in the development of carbon capture technologies (i.e., the option premium) while the carbon price is low, a company will have the ability, but not the obligation to implement this technology quickly when the market carbon price corrects and benefit by capturing the unlimited upside potential.

Carbon mineralization has additional value because it provides managers with the flexibility to capitalize on favorable future opportunities or to limit losses by taking a future action. This value is driven by five attributes [156]. First is the value of the underlying asset (e.g., stock price, S), which in this case is the SCC. The second is the cost of sequestering carbon (e.g., exercise price, X). The third variable is the risk free rate (rf). The fourth is the variance (uncertainty or risk, $\sigma^{2}$ ) in the returns of the underlying asset, which in this case is the volatility of the price of carbon. The fifth is the time to get the project to maturity (e.g., expiration date, t). All things considered, the longer the time to maturity and the more volatility in the carbon price, the greater the value of the option.

A quick glance at Table 3, reveals that the real options valuation method has a much more complex decision making criteria compared to the simpler finite life resource and NPV models. A key difference between real options and the other two models is that real options consider the length of time until a manager must make the decision. The major shortfall of the two simpler models is their inability to incorporate operating flexibility and growth-opportunities faced by the company. The real options approach recognizes most projects are multi-stage and the decision to proceed, suspend, or abandon the project has value. First, since the mining company does not have to pay until it exercises the option, it can use that money for other investments today which takes into consideration the time value of money. Second, the mining company does not need to exercise the option and wait until the price of carbon is sufficiently high. NPV also does not consider the volatility of the carbon price, which is a key driver of the real options value. The greater the volatility of the carbon price, the more valuable the option will be for the mining company as it will be able to pursue this opportunity with its significant upside potential while the option completely insulates it from low carbon prices. 
Table 3. Comparison of three valuation approaches.

\begin{tabular}{llll}
\hline Investment Opportunity & Finite Life Resource & Net Present Value & Real Options Valuation \\
\hline $\begin{array}{l}\text { Present value of the project's } \\
\text { underlying assets }\end{array}$ & Price of carbon $(\mathrm{S})$ & Price of carbon $(\mathrm{S})$ & Price of Carbon $\left(\mathrm{S}_{0}\right)$ \\
\hline $\begin{array}{l}\text { Expenditure required to } \\
\text { acquire the project assets }\end{array}$ & Cost to sequester carbon $(\mathrm{X})$ & Cost to sequester carbon $(\mathrm{X})$ & Cost of sequestering carbon $(\mathrm{X})$ \\
\hline Time value of money & & Cost of capital $(\mathrm{r})$ & Real risk free rate $(\mathrm{rf})$ \\
\hline $\begin{array}{l}\text { Riskiness of the project assets } \\
\text { Length of time the decision } \\
\text { may be deferred }\end{array}$ & Incorporated into $\mathrm{r}$ & Volatility of carbon price $\left(\sigma^{2}\right)$ \\
\hline & & Time to get project to maturity $(\mathrm{t})$
\end{tabular}


The real options approach recognizes the value can be realized in making an initial modest investment and then timing market entry [155]; this type of flexibility in corporate resource allocation has proven vital to long-term success in an uncertain and changing marketplace. One of the main implications of applying real options theory is that it helps companies battle, capitalize on and even befriend uncertainty [157]. Overlooking the options-like characteristic of this project could result in poor decision making and a missed opportunity. Real options have been around for more than three decades, yet are used by a very small proportion of managers because of "lack of expertise and knowledge" [158]. Companies who invest in this carbon mineralization technology in uncertain times will have future flexibility and can benefit from having the right, but not the obligation, to shift activities or take action in the future. The real options approach will capture the value inherent in the option for mining companies to enter into and profit from the highly volatile carbon market when the future price of carbon aligns with the SCC.

\section{Challenges and Summary}

Research teams will continue to advance our understanding of the fundamentals underlying carbon mineralization; however, overcoming the technological challenges of implementing carbon mineralization at mine sites requires investment from mining industry partners to test carbon mineralization processes at the pilot scale. Enhanced passive carbonation is a relatively simple approach with strategies being as straightforward as increasing the areal footprint of the TSF, yet more extensive carbon mineralization will require more involved engineering strategies. Many existing technologies such as bioreactors for biofuels could be adapted for the purpose of carbon mineralization at mine sites. There is universal recognition that carbon is currently undervalued in the market and this is problematic because there is no economic incentive for companies to reduce emissions. However, markets self-correct and we must recognize that the carbon market will become more efficient as market forces move the carbon price closer to its intrinsic value. In anticipation of this, companies should use a real options pricing approach, which will capture the inherent value associated with the flexibility for managers to defer, expand, contract, abandon, switch use, or otherwise alter a capital investment, in response to future carbon price volatility. Implementation of a combination of acceleration strategies as discussed in this review has the potential to render large mines carbon-neutral, should managers choose to invest in this option.

\section{Acknowledgments}

We acknowledge the support of Carbon Management Canada through a research grant to Gregory M. Dipple, Gordon Southam and Siobhan A. Wilson and the Natural Sciences and Engineering Research Council (NSERC) of Canada for research grants to Gregory M. Dipple and Gordon Southam. Jenine McCutcheon was supported by an NSERC M.Sc. scholarship, and Anna L. Harrison was supported by an NSERC Ph.D. scholarship. We thank the guest editor, Tuncel Yegulalp, as well as the two anonymous reviewers for their insightful comments. This is publication 331 of the Mineral Deposit Research Unit. 


\section{Author Contributions}

For this review, each author contributed to drafting and editing the manuscript. Ian M. Power coordinated the review and drafted the figures.

\section{Conflicts of Interest}

The authors declare no conflict of interest.

\section{References}

1. Gerdemann, S.J.; O’Connor, W.K.; Dahlin, D.C.; Penner, L.R.; Rush, H. Ex situ aqueous mineral carbonation. Environ. Sci. Technol. 2007, 41, 2587-2593.

2. Lackner, K.S.; Wendt, C.H.; Butt, D.P.; Joyce, E.L., Jr.; Sharp, D.H. Carbon dioxide disposal in carbonate minerals. Energy 1995, 20, 1153-1170.

3. Zevenhoven, R.; Fagerlund, J.; Songok, J.K. $\mathrm{CO}_{2}$ mineral sequestration: Developments toward large-scale application. Greenh. Gas Sci. Technol. 2011, 1, 48-57.

4. International Energy Agency (IEA). $\mathrm{CO}_{2}$ Capture and Storage: A Key Carbon Abatement Option; IEA: Paris, France, 2008.

5. Pellegrino, C.; Lodhia, S. Climate change accounting and the Australian mining industry: Exploring the links between corporate disclosure and the generation of legitimacy. J. Clean Prod. 2012, 36, 68-82.

6. Köhler, P.; Hartmann, J.; Wolf-Gladrow, D.A. Geoengineering potential of artificially enhanced silicate weathering of olivine. Proc. Natl. Acad. Sci. USA 2010, 107, 20228-20233.

7. Schuiling, R.D.; Krijgsman, P. Enhanced weathering: An effective and cheap tool to sequester $\mathrm{CO}_{2}$. Clim. Chang. 2006, 74, 349-354.

8. Washbourne, C.L.; Renforth, P.; Manning, D.A.C. Investigating carbonate formation in urban soils as a method for capture and storage of atmospheric carbon. Sci. Total Environ. 2012, 431, $166-175$.

9. Renforth, P. The potential of enhanced weathering in the UK. Int. J. Greenh. Gas Control 2012, 10, 229-243.

10. Renforth, P.; Manning, D.A.C. Laboratory carbonation of artificial silicate gels enhanced by citrate: Implications for engineered pedogenic carbonate formation. Int. J. Greenh. Gas Control 2011, 5, 1578-1586.

11. Bea, S.A.; Wilson, S.A.; Mayer, K.U.; Dipple, G.M.; Power, I.M.; Gamazo, P. Reactive transport modeling of natural carbon sequestration in ultramafic mine tailings. Vadose Zone J. 2012, 11, doi:10.2136/vzj2011.0053.

12. Mills, S.J.; Wilson, S.A.; Dipple, G.M.; Raudsepp, M. The decomposition of konyaite: importance in $\mathrm{CO}_{2}$ fixation in mine tailings. Mineral. Mag. 2010, 74, 903-917.

13. Power, I.M.; Dipple, G.M.; Southam, G. Bioleaching of ultramafic tailings by Acidithiobacillus spp. for $\mathrm{CO}_{2}$ Sequestration. Environ. Sci. Technol. 2010, 44, 456-462.

14. Power, I.M.; Wilson, S.A.; Dipple, G.M. Serpentinite carbonation for $\mathrm{CO}_{2}$ sequestration. Elements 2013, 9, 115-121. 
15. Power, I.M.; Wilson, S.A.; Small, D.P.; Dipple, G.M.; Wan, W.K.; Southam, G. Microbially mediated mineral carbonation: Roles of phototrophy and heterotrophy. Environ. Sci. Technol. 2011, 45, 9061-9068.

16. Wilson, S.A.; Barker, S.L.L.; Dipple, G.M.; Atudorei, V. Isotopic disequilibrium during uptake of atmospheric $\mathrm{CO}_{2}$ into mine process waters: Implications for $\mathrm{CO}_{2}$ sequestration. Environ. Sci. Technol. 2010, 44, 9522-9529.

17. Wilson, S.A.; Dipple, G.M.; Power, I.M.; Barker, S.L.L.; Fallon, S.J.; Southam, G. Subarctic weathering of mineral wastes provides a sink for atmospheric $\mathrm{CO}_{2}$. Environ. Sci. Technol. 2011, 45, 7727-7736.

18. Wilson, S.A.; Dipple, G.M.; Power, I.M.; Thom, J.M.; Anderson, R.G.; Raudsepp, M.; Gabites, J.E.; Southam, G. Carbon dioxide fixation within mine wastes of ultramafic-hosted ore deposits: Examples from the Clinton Creek and Cassiar chrysotile deposits, Canada. Econ. Geol. 2009, 104, 95-112.

19. Wilson, S.A.; Harrison, A.L.; Dipple, G.M.; Power, I.M.; Barker, S.L.L.; Mayer, K.U.; Fallon, S.J.; Raudsepp, M.; Southam, G. Offsetting of $\mathrm{CO}_{2}$ emissions by air capture in mine tailings at the Mount Keith Nickel Mine, Western Australia: Rates, controls and prospects for carbon neutral mining. Int. J. Greenh. Gas Control 2014, in press.

20. Wilson, S.A.; Raudsepp, M.; Dipple, G.M. Verifying and quantifying carbon fixation in minerals from serpentine-rich mine tailings using the Rietveld method with X-ray powder diffraction data. Am. Miner. 2006, 91, 1331-1341.

21. Wilson, S.A.; Raudsepp, M.; Dipple, G.M. Quantifying carbon fixation in trace minerals from processed kimberlite: A comparative study of quantitative methods using X-ray powder diffraction data with applications to the Diavik Diamond Mine, Northwest Territories, Canada. Appl. Geochem. 2009, 24, 2312-2331.

22. Assima, G.P.; Larachi, F.; Beaudoin, G.; Molson, J. $\mathrm{CO}_{2}$ Sequestration in chrysotile mining residues-implication of watering and passivation under environmental conditions. Ind. Eng. Chem. Res. 2012, 51, 8726-8734.

23. Assima, G.P.; Larachi, F.; Beaudoin, G.; Molson, J. Dynamics of carbon dioxide uptake in chrysotile mining residues-Effect of mineralogy and liquid saturation. Int. J. Greenh. Gas Control 2013, 12, 124-135.

24. Pronost, J.; Beaudoin, G.; Lemieux, J.M.; Hebert, R.; Constantin, M.; Marcouiller, S.; Klein, M.; Duchesne, J.; Molson, J.W.; Larachi, F.; Maldague, X. $\mathrm{CO}_{2}$-depleted warm air venting from chrysotile milling waste (Thetford Mines, Canada): Evidence for in-situ carbon capture from the atmosphere. Geology 2012, 40, 275-278.

25. Pronost, J.; Beaudoin, G.; Tremblay, J.; Larachi, F.; Duchesne, J.; Hebert, R.; Constantin, M. Carbon sequestration kinetic and storage capacity of ultramafic mining waste. Environ. Sci. Technol. 2011, 45, 9413-9420.

26. Beinlich, A.; Austrheim, H. In situ sequestration of atmospheric $\mathrm{CO}_{2}$ at low temperature and surface cracking of serpentinized peridotite in mine shafts. Chem. Geol. 2012, 332, 32-44.

27. Goff, F.; Lackner, K.S. Carbon dioxide sequestering using ultramafic rocks. Environ. Geosci. 1998, 5, 89-101. 
28. Harrison, A.L.; Power, I.M.; Dipple, G.M. Accelerated carbonation of brucite in mine tailings for carbon sequestration. Environ. Sci. Technol. 2013, 47, 126-134.

29. Assima, G.P.; Larachi, F.; Molson, J.; Beaudoin, G. Impact of temperature and oxygen availability on the dynamics of ambient $\mathrm{CO}_{2}$ mineral sequestration by nickel mining residues. Chem. Eng. J. 2014, 240, 394-403.

30. Levitan, D.M.; Hammarstrom, J.M.; Gunter, M.E.; Seal, R.R.; Chou, I.M.; Piatak, N.M. Mineralogy of mine waste at the Vermont Asbestos Group mine, Belvidere Mountain, Vermont. Am. Miner. 2009, 94, 1063-1066.

31. Price, W.A. Challenges Posed by Metal Leaching and Acid Rock Drainage, and Approaches to Addressing Them. In Environmental Aspects of Mine Wastes; Jambor, J.L., Blowes, D.W., Ritchie, A.I.M., Eds.; Mineralogical Association of Canada: Quebec City, QC, Canada, 2003; pp. 1-10.

32. Salek, S.S.; Kleerebezem, R.; Jonkers, H.M.; Witkamp, G.J.; van Loosdrecht, M.C.M. Mineral $\mathrm{CO}_{2}$ sequestration by environmental biotechnological processes. Trends Biotechnol. 2013, 31, 139-146.

33. McCutcheon, J.; Power, I.M.; Harrison, A.; Small, D.; Pirani, A.; Dipple, G.; Southam, G.; Microbially-Accelerated Carbon Sequestration: Magnesium Carbonate Mineralization in Mine Waste. In Proceedings of 22nd V.M. Goldschmidt Conference, Montréal, QC, Canada, 24-29 June 2012.

34. U.S. Environmental Protection Agency (USEPA). Quantifying Greenhouse Gas Emissions from Key Industrial Sectors in the United States; USEPA: Washington, DC, USA, 2008. Available online: http://www.epa.gov/sectors/pdf/greenhouse-report.pdf (acessed on 1 July 2013).

35. Power, I.M.; Harrison, A.L.; Dipple, G.M.; Wilson, S.A.; Kelemen, P.B.; Hitch, M.; Southam, G. Carbon Mineralization: From Natural Analogues to Engineered Systems. In Geochemistry of Geologic $\mathrm{CO}_{2}$ Sequestration; DePaolo, D.J., Cole, D.R., Navrotsky, A., Bourg, I.C., Eds.; The Mineralogical Society of America: Chantilly, VA, USA, 2013; Volume 77, pp. 305-360.

36. WMC Resources Ltd. Annual Sustainability Report 2004; WMC Resources Ltd.: Melbourne, Australia, 2005.

37. Power, I.M.; Wilson, S.A.; Dipple, G.M.; Southam, G. Modern carbonate microbialites from an asbestos open pit pond, Yukon, Canada. Geobiology 2011, 9, 180-195.

38. Thom, J.M.; Dipple, G.M.; Power, I.M.; Harrison, A.L. Chrysotile dissolution rates: Implications for carbon sequestration. Appl. Geochem. 2013, 35, 244-254.

39. Power, I.M.; Harrison, A.L.; Dipple, G.M.; Southam, G. Carbon sequestration via carbonic anhydrase facilitated magnesium carbonate precipitation. Int. J. Greenh. Gas Control 2013, 16, $145-155$.

40. Harrison, A.L.; Power, I.M.; Dipple, G.M. Strategies for Enhancing Carbon Sequestration in Mg-Rich Mine Tailings. In Proceedings of International Mine Water Association 2013 Annual Conference, Denver, CO, USA, 6-9 August 2013; Brown, A., Figueroa, L., Wolkersdorfer, C., Eds.; pp. 593-599.

41. Diavik Diamond Mine. 2011 Sustainable Development Report; Diavik Diamond Mine: Yellowknife, NT, Canada, 2011. 
42. Oskierski, H.C.; Dlugogorski, B.Z.; Jacobsen, G. Sequestration of atmospheric $\mathrm{CO}_{2}$ in chrysotile mine tailings of the Woodsreef Asbestos Mine, Australia: Quantitative mineralogy, isotopic fingerprinting and carbonation rates. Chem. Geol. 2013, 358, 156-169.

43. Hostetler, P.B.; Coleman, R.G.; Mumpton, F.A.; Evan, B.W. Brucite in alpine serpentinites. Am. Miner. 1966, 51, 75-98.

44. O’Neil, J.R.; Barnes, I. $\mathrm{C}^{13}$ and $\mathrm{O}^{18}$ compositions in some fresh-water carbonates associated with ultramafic rocks and serpentinites: Western United States. Geochim. Cosmochim. Acta 1971, 35, 687-697.

45. Königsberger, E.; Königsberger, L.; Gamsjager, H. Low-temperature thermodynamic model for the system $\mathrm{Na}_{2} \mathrm{CO}_{3}-\mathrm{MgCO}_{3}-\mathrm{CaCO}_{3}-\mathrm{H}_{2} \mathrm{O}$. Geochim. Cosmochim. Acta 1999, 63, 3105-3119.

46. Hänchen, M.; Prigiobbe, V.; Baciocchi, R.; Mazzotti, M. Precipitation in the Mg-carbonate system-Effects of temperature and $\mathrm{CO}_{2}$ pressure. Chem. Eng. Sci. 2008, 63, 1012-1028.

47. Schuiling, R.D.; Wilson, S.A.; Power, I.M. Enhanced silicate weathering is not limited by silicic acid saturation. Proc. Natl. Acad. Sci. USA 2011, 108, E41-E41.

48. Huh, Y.S. Chemical weathering and climate-A global experiment: A review. Geosci. J. 2003, 7, 277-288.

49. Amiotte Suchet, P.; Probst, J.L.; Ludwig, W. Worldwide distribution of continental rock lithology: Implications for the atmospheric/soil $\mathrm{CO}_{2}$ uptake by continental weathering and alkalinity river transport to the oceans. Glob. Biogeochem. Cycles 2003, 17, doi:10.1029/2002GB001891.

50. Torsvik, V.; Sørheim, R.; Goksøyr, J. Total bacterial diversity in soil and sediment communities-A review. J. Indust. Microbiol. 1996, 17, 170-178.

51. Power, I.M.; Wilson, S.A.; Thom, J.M.; Dipple, G.M.; Southam, G. Biologically induced mineralization of dypingite by cyanobacteria from an alkaline wetland near Atlin, British Columbia, Canada. Geochem. Trans. 2007, 8, doi:10.1186/1467-4866-8-13.

52. Bales, R.C.; Morgan, J.J. Dissolution kinetics of chrysotile at pH 7 to 10. Geochim. Cosmochim. Acta 1985, 49, 2281-2288.

53. Pokrovsky, O.S.; Schott, J. Kinetics and mechanism of forsterite dissolution at $25{ }^{\circ} \mathrm{C}$ and $\mathrm{pH}$ from 1 to 12. Geochim. Cosmochim. Acta 2000, 64, 3313-3325.

54. Pokrovsky, O.S.; Schott, J. Experimental study of brucite dissolution and precipitation in aqueous solutions: Surface speciation and chemical affinity control. Geochim. Cosmochim. Acta 2004, 68, 31-45.

55. Daval, D.; Hellmann, R.; Martinez, I.; S., G.; Guyot, F. Lizardite serpentine dissolution kinetics as a function of $\mathrm{pH}$ and temperature, including effects of elevated $\mathrm{CO}_{2}$. Chem. Geol. 2013, 351, 245-256.

56. Yao, M.J.; Lian, B.; Teng, H.H.; Tian, Y.C.; Yang, X.Q. Serpentine dissolution in the presence of bacteria Bacillus mucilaginosus. Geomicrobiol. J. 2013, 30, 72-80.

57. Chiang, Y.W.; Santos, R.M.; Monballiu, A.; Ghyselbrecht, K.; Martens, J.A.; Mattos, M.L.T.; Van Gerven, T.; Meesschaert, B. Effects of bioleaching on the chemical, mineralogical and morphological properties of natural and waste-derived alkaline materials. Miner. Eng. 2013, 48, $116-125$. 
58. Burford, E.P.; Fomina, M.; Gadd, G.M. Fungal involvement in bioweathering and biotransformation of rocks and minerals. Mineral. Mag. 2003, 67, 1127-1155.

59. Padilla, G.A.; Cisternas, L.A.; Cueto, J.Y. On the optimization of heap leaching. Miner. Eng. 2008, 21, 673-678.

60. Bosecker, K. Bioleaching: Metal solubilization by microorganisms. FEMS Microbiol. Rev. 1997, 20, 591-604.

61. Johnson, D.B.; Grail, B.M.; Hallberg, K.B. A new direction for biomining: Extraction of metals by reductive dissolution of oxidized ores. Minerals 2013, 3, 49-58.

62. Fortin, D.; Davis, B.; Beveridge, T.J. Role of Thiobacillus and sulfate-reducing bacteria in iron biocycling in oxic and acidic mine tailings. FEMS Microbiol. Ecol. 1996, 21, 11-24.

63. Mielke, R.E.; Pace, D.L.; Porter, T.; Southam, G. A critical stage in the formation of acid mine drainage: Colonization of pyrite by Acidithiobacillus ferrooxidans under $\mathrm{pH}-\mathrm{neutral}$ conditions. Geobiology 2003, 1, 81-90.

64. Nordstrom, D.K.; Southam, G. Geomicrobiology of sulfide mineral oxidation. In Geomicrobiology: Interactions between Microbes and Minerals; Banfield, J.F., Nealson, K.H., Eds.; The Mineralogical Society of America: Chantilly, VA, USA, 1997; Volume 35, pp. 361-390.

65. Gould, W.D.; Kapoor, A. Chapter 10. The Microbiology of Acid Mine Drainage. In Environmental Aspects of Mine Wastes; Jambor, J.L., Blowes, D.W., Ritchie, A.I.M., Eds.; Mineralogical Association of Canada: Quebec City, QC, Canada, 2003; Volume 31, pp. 203-226.

66. Edwards, K.J.; Goebel, B.M.; Rodgers, T.M.; Schrenk, M.O.; Gihring, T.M.; Cardona, M.M.; Hu, B.; McGuire, M.M.; Hamers, R.J.; Pace, N.R.; Banfield, J.F. Geomicrobiology of pyrite $\left(\mathrm{FeS}_{2}\right)$ dissolution: Case study at Iron Mountain, California. Geomicrobiol. J. 1999, 16, 155-179.

67. Singer, P.C.; Stumm, W. Acidic mine drainage: The rate determining step. Science 1970, 167, 1121-1123.

68. Kirby, C.S.; Thomas, H.M.; Southam, G.; Donald, R. Relative contributions of abiotic and biological factors in Fe(II) oxidation in mine drainage. Appl. Geochem. 1999, 14, 511-530.

69. Cameron, R.A.; Lastra, R.; Mortazavi, S.; Bedard, P.L.; Morin, L.; Gould, W.D.; Kennedy, K.J. Bioleaching of a low-grade ultramafic nickel sulphide ore in stirred-tank reactors at elevated $\mathrm{pH}$. Hydrometallurgy 2009, 97, 213-220.

70. Cameron, R.A.; Lastra, R.; Mortazavi, S.; Gould, W.D.; Thibault, Y.; Bedard, P.L.; Morin, L.; Kennedy, K.J. Elevated-pH bioleaching of a low-grade ultramafic nickel sulphide ore in stirred-tank reactors at 5 to 45 degrees C. Hydrometallurgy 2009, 99, 77-83.

71. Cameron, R.A.; Yeung, C.W.; Greer, C.W.; Gould, W.D.; Mortazavi, S.; Bedard, P.L.; Morin, L.; Lortie, L.; Dinardo, O.; Kennedy, K.J. The bacterial community structure during bioleaching of a low-grade nickel sulphide ore in stirred-tank reactors at different combinations of temperature and pH. Hydrometallurgy 2010, 104, 207-215.

72. McDonald, R.G.; Whittington, B.I. Atmospheric acid leaching of nickel laterites review. Part II. Chloride and bio-technologies. Hydrometallurgy 2008, 91, 56-69.

73. Qin, W.Q.; Zhen, S.J.; Yan, Z.Q.; Campbell, M.; Wang, J.; Liu, K.; Zhang, Y.S. Heap bioleaching of a low-grade nickel-bearing sulfide ore containing high levels of magnesium as olivine, chlorite and antigorite. Hydrometallurgy 2009, 98, 58-65. 
74. Zhen, S.J.; Yan, Z.Q.; Zhang, Y.S.; Wang, J.; Campbell, M.; Qin, W.Q. Column bioleaching of a low grade nickel-bearing sulfide ore containing high magnesium as olivine, chlorite and antigorite. Hydrometallurgy 2009, 96, 337-341.

75. Yang, C.R.; Qin, W.Q.; Lai, S.S.; Wang, J.; Zhang, Y.S.; Jiao, F.; Ren, L.Y.; Zhuang, T.A.; Chang, Z.Y. Bioleaching of a low grade nickel-copper-cobalt sulfide ore. Hydrometallurgy 2011, 106, 32-37.

76. Jambor, J.L. Mine-Waste Mineralogy and Mineralogical Perspectives of Acid-Base Acounting. In Environmental Aspects of Mine Wastes; Jambor, J.L., Blowes, D.W., Ritchie, A.I. M., Eds.; Mineralogical Association of Canada: Quebec City, QC, Canada, 2003; pp. 117-146.

77. Stumm, W.; Morgan, J.J. Aquatic Chemistry-Chemical Equilibria and Rates in Natural Waters, 3rd ed.; Wiley: New York, NY, USA, 1996.

78. Bass, D.H.; Hastings, N.A.; Brown, R.A. Performance of air sparging systems: A review of case studies. J. Hazard. Mater. 2000, 72, 101-119.

79. Kabelitz, N.; Machackova, J.; Imfeld, G.; Brennerova, M.; Pieper, D.H.; Heipieper, H.J.; Junca, H. Enhancement of the microbial community biomass and diversity during air sparging bioremediation of a soil highly contaminated with kerosene and BTEX. Appl. Microbiol. Biotechnol. 2009, 82, $565-577$.

80. Pokrovsky, O.S.; Schott, J.; Castillo, A. Kinetics of brucite dissolution at 25 degrees C in the presence of organic and inorganic ligands and divalent metals. Geochim. Cosmochim. Acta 2005, 69, 905-918.

81. Bobicki, E.R.; Liu, Q.X.; Xu, Z.H.; Zeng, H.B. Carbon capture and storage using alkaline industrial wastes. Prog. Energy Combust. Sci. 2012, 38, 302-320.

82. Michael, K.; Allinson, G.; Golab, A.; Sharma, S.; Shulakova, V. $\mathrm{CO}_{2}$ Storage in Saline Aquifers II-Experience from Existing Storage Operations. In Greenhouse Gas Control Technologies 9; Gale, J., Herzog, H., Braitsch, J., Eds.; Elsevier Science BV: Amsterdam, The Netherlands, 2009; Volume 1, pp. 1973-1980.

83. Bickle, M.; Chadwick, A.; Huppert, H.E.; Hallworth, M.; Lyle, S. Modelling carbon dioxide accumulation at Sleipner: Implications for underground carbon storage. Earth Planet. Sci. Lett. 2007, 255, 164-176.

84. Ragnheidardottir, E.; Sigurdardottir, H.; Kristjansdottir, H.; Harvey, W. Opportunities and challenges for CarbFix: An evaluation of capacities and costs for the pilot scale mineralization sequestration project at Hellisheidi, Iceland and beyond. Int. J. Greenh. Gas Control 2011, 5, 1065-1072.

85. Aradottir, E.S.P.; Sigurdardottir, H.; Sigfusson, B.; Gunnlaugsson, E. CarbFix: A CCS pilot project imitating and accelerating natural $\mathrm{CO}_{2}$ sequestration. Greenh. Gases 2011, 1, 105-118.

86. Steefel, C.I.; Molins, S.; Trebotich, D. Pore Scale Processes Associated with Subsurface $\mathrm{CO}_{2}$ Injection and Sequestration. In Geochemistry of Geologic $\mathrm{CO}_{2}$ Sequestration; DePaolo, D.J., Cole, D.R., Navrotsky, A., Bourg, I.C., Eds.; Mineralogical Society of America: Chantilly, VA, USA, 2013; Volume 77, pp. 259-303.

87. Warthmann, R.; van Lith, Y.; Vasconcelos, C.; McKenzie, J.A.; Karpoff, A.M. Bacterially induced dolomite precipitation in anoxic culture experiments. Geology 2000, 28, 1091-1094. 
88. López-García, P.; Kazmierczak, J.; Benzerara, K.; Kempe, S.; Guyot, F.; Moreira, D. Bacterial diversity and carbonate precipitation in the giant microbialites from the highly alkaline Lake Van, Turkey. Extremophiles 2005, 9, 263-274.

89. Rodriguez-Navarro, C.; Jimenez-Lopez, C.; Rodriguez-Navarro, A.; Gonzalez-Muñoz, M.T.; Rodriguez-Gallego, M. Bacterially mediated mineralization of vaterite. Geochim. Cosmochim. Acta 2007, 71, 1197-1213.

90. Von Knorre, H.; Krumbein, W.E. Bacterial Calcification. In Microbial Sediments; Riding, R.E., Awramik, S.M., Eds.; Springer: Berlin, Germany, 2000; pp. 25-31.

91. Mitchell, A.C.; Dideriksen, K.; Spangler, L.H.; Cunningham, A.B.; Gerlach, R. Microbially enhanced carbon capture and storage by mineral-trapping and solubility-trapping. Environ. Sci. Technol. 2010, 44, 5270-5276.

92. Lindsay, M.B.J.; Blowes, D.W.; Condon, P.D.; Ptacek, C.J. Organic carbon amendments for passive in situ treatment of mine drainage: Field experiments. Appl. Geochem. 2011, 26, 1169-1183.

93. Lindsay, M.B.J.; Wakeman, K.D.; Rowe, O.F.; Grail, B.M.; Ptacek, C.J.; Blowes, D.W.; Johnson, D.B. Microbiology and geochemistry of mine tailings amended with organic carbon for passive treatment of pore water. Geomicrobiol. J. 2011, 28, 229-241.

94. Pepper, I.L.; Zerzghi, H.G.; Bengson, S.A.; Iker, B.C.; Banerjee, M.J.; Brooks, J.P. Bacterial populations within copper mine tailings: Long-term effects of amendment with Class A biosolids. J. Appl. Microbiol. 2012, 113, 569-577.

95. Madejon, E.; Doronila, A.I.; Madejon, P.; Baker, A.J.M.; Woodrow, I.E. Biosolids, mycorrhizal fungi and eucalypts for phytostabilization of arsenical sulphidic mine tailings. Agrofor. Syst. 2012, 84, 389-399.

96. Gardner, W.C.; Naeth, M.A.; Broersma, K.; Chanasyk, D.S.; Jobson, A.M. Influence of biosolids and fertilizer amendments on element concentrations and revegetation of copper mine tailings. Can. J. Soil Sci. 2012, 92, 89-102.

97. Salek, S.S.; Kleerebezem, R.; Jonkers, H.M.; Voncken, J.H.L.; van Loosdrecht, M.C.M. Determining the impacts of fermentative bacteria on wollastonite dissolution kinetics. Appl. Microbiol. Biotechnol. 2013, 97, 2743-2752.

98. Ferris, F.G.; Wiese, R.G.; Fyfe, W.S. Precipitation of carbonate minerals by microorganisms: Implications for silicate weathering and the global carbon dioxide budget. Geomicrobiol. J. 1994, 12, 1-13.

99. Riding, R. Microbial carbonates: The geological record of calcified bacterial-algal mats and biofilms. Sedimentology 2000, 47, 179-214.

100. Roberts, J.A.; Bennett, P.C.; Gonzalez, L.A.; Macpherson, G.L.; Milliken, K.L. Microbial precipitation of dolomite in methanogenic groundwater. Geology 2004, 32, 277-280.

101. Dupraz, C.; Reid, R.P.; Braissant, O.; Decho, A.W.; Norman, R.S.; Visscher, P.T. Processes of carbonate precipitation in modern microbial mats. Earth-Sci. Rev. 2009, 96, 141-162.

102. Riding, R. Cyanobacterial calcification, carbon dioxide concentrating mechanisms, and Proterozoic-Cambrian changes in atmospheric composition. Geobiology 2006, 4, 299-316.

103. Jansson, C.; Northen, T. Calcifying cyanobacteria-the potential of biomineralization for carbon capture and storage. Curr. Opin. Biotechnol. 2010, 21, 365-371. 
104. Kamennaya, N.A.; Ajo-Franklin, C.M.; Northen, T.; Jansson, C. Cyanobacteria as Biocatalysts for Carbonate Mineralization. Minerals 2012, 2, 338-364.

105. Kaplan, A.; Reinhold, L. $\mathrm{CO}_{2}$ concentrating mechanisms in photosynthetic microorganisms. Annu. Rev. Plant Physiol. Plant Molec. Biol. 1999, 50, 539-570.

106. Badger, M.R.; Price, G.D. $\mathrm{CO}_{2}$ concentrating mechanisms in cyanobacteria: Molecular components, their diversity and evolution. J. Exp. Bot. 2003, 54, 609-622.

107. Thompson, J.B.; Ferris, F.G. Cyanobacterial precipitation of gypsum, calcite, and magnesite from natural alkaline lake water. Geology 1990, 18, 995-998.

108. Schultze-Lam, S.; Beveridge, T.J. Physicochemical characteristics of the mineral-forming S-layer from the cyanobacterium Synechococcus strain G124. Can. J. Microbiol. 1994, 40, 216-223.

109. Schultze-Lam, S.; Fortin, D.; Davis, B.S.; Beveridge, T.J. Mineralization of bacterial surfaces. Chem. Geol. 1996, 132, 171-181.

110. Obst, M.; Dittrich, M.; Kuehn, H. Calcium adsorption and changes of the surface microtopography of cyanobacteria studied by AFM, CFM, and TEM with respect to biogenic calcite nucleation. Geochem. Geophys. Geosyst. 2006, 7, Q06011, doi:10.1029/2005GC001172.

111. Dudev, T.; Cowan, J.A.; Lim, C. Competitive binding in magnesium coordination chemistry: Water versus ligands of biological interest. J. Am. Chem. Soc. 1999, 121, 7665-7673.

112. Zhang, F.F.; Xu, H.F.; Konishi, H.; Shelobolina, E.S.; Roden, E.E. Polysaccharide-catalyzed nucleation and growth of disordered dolomite: A potential precursor of sedimentary dolomite. Am. Miner. 2012, 97, 556-567.

113. Roberts, J.A.; Kenward, P.A.; Fowle, D.A.; Goldstein, R.H.; Gonzalez, L.A.; Moore, D.S. Surface chemistry allows for abiotic precipitation of dolomite at low temperature. Proc. Natl. Acad. Sci. USA 2013, 110, 14540-14545.

114. Slaughter, M.; Hill, R.J. The influence of organic matter in organogenic dolomitization. J. Sediment. Petrol. 1991, 61, 296-303.

115. Wright, D.T.; Wacey, D. Precipitation of dolomite using sulphate-reducing bacteria from the Coorong Region, South Australia: Significance and implications. Sedimentology 2005, 52, 987-1008.

116. Kluge, S.; Weston, J. Can a hydroxide ligand trigger a change in the coordination number of magnesium ions in biological systems. Biochemistry 2005, 44, 4877-4885.

117. Fenter, P.; Zhang, Z.; Park, C.; Sturchio, N.C.; Hu, X.M.; Higgins, S.R. Structure and reactivity of the dolomite (104)-water interface: New insights into the dolomite problem. Geochim. Cosmochim. Acta 2007, 71, 566-579.

118. Couradeau, E.; Benzerara, K.; Gerard, E.; Moreira, D.; Bernard, S.; Brown, G.E.; Lopez-Garcia, P. An early-branching microbialite cyanobacterium forms intracellular carbonates. Science 2012, $336,459-462$.

119. Shirokova, L.S.; Mavromatis, V.; Bundeleva, I.A.; Pokrovsky, O.S.; Benezeth, P.; Gerard, E.; Pearce, C.R.; Oelkers, E.H. Using Mg isotopes to trace cyanobacterially mediated magnesium carbonate precipitation in alkaline lakes. Aquat. Geochem. 2013, 19, 1-24.

120. Yang, Y.; Gao, K.S. Effects of $\mathrm{CO}_{2}$ concentrations on the freshwater microalgae, Chlamydomonas reinhardtii, Chlorella pyrenoidosa and Scenedesmus obliquus (Chlorophyta). J. Appl. Phycol. 2003, 15, 379-389. 
121. Beardall, J.; Raven, J.A. The potential effects of global climate change on microalgal photosynthesis, growth and ecology. Phycologia 2004, 43, 26-40.

122. Ramos, J.B.E.; Biswas, H.; Schulz, K.G.; LaRoche, J.; Riebesell, U. Effect of rising atmospheric carbon dioxide on the marine nitrogen fixer Trichodesmium. Glob. Biogeochem. Cycle 2007, 21, GB2028, doi:10.1029/2006GB002898.

123. Levitan, O.; Rosenberg, G.; Setlik, I.; Setlikova, E.; Grigel, J.; Klepetar, J.; Prasil, O.; Berman-Frank, I. Elevated $\mathrm{CO}_{2}$ enhances nitrogen fixation and growth in the marine cyanobacterium Trichodesmium. Glob. Chang. Biol. 2007, 13, 531-538.

124. Riebesell, U.; Schulz, K.G.; Bellerby, R.G.J.; Botros, M.; Fritsche, P.; Meyerhofer, M.; Neill, C.; Nondal, G.; Oschlies, A.; Wohlers, J.; Zollner, E. Enhanced biological carbon consumption in a high $\mathrm{CO}_{2}$ ocean. Nature 2007, 450, 545-548.

125. Fu, F.X.; Warner, M.E.; Zhang, Y.H.; Feng, Y.Y.; Hutchins, D.A. Effects of increased temperature and $\mathrm{CO}_{2}$ on photosynthesis, growth, and elemental ratios in marine Synechococcus and Prochlorococcus (Cyanobacteria). J. Phycol. 2007, 43, 485-496.

126. Ramanan, R.; Kannan, K.; Deshkar, A.; Yadav, R.; Chakrabarti, T. Enhanced algal $\mathrm{CO}_{2}$ sequestration through calcite deposition by Chlorella sp. and Spirulina platensis in a mini-raceway pond. Bioresour. Technol. 2010, 101, 2616-2622.

127. Lee, S.W.; Park, S.B.; Jeong, S.K.; Lim, K.S.; Lee, S.H.; Trachtenberg, M.C. On carbon dioxide storage based on biomineralization strategies. Micron 2010, 41, 273-282.

128. Ramanan, R.; Kannan, K.; Sivanesan, S.D.; Mudliar, S.; Kaur, S.; Tripathi, A.K.; Chakrabarti, T. Bio-sequestration of carbon dioxide using carbonic anhydrase enzyme purified from Citrobacter freundii. World J. Microb. Biot. 2009, 25, 981-987.

129. Sharma, A.; Bhattacharya, A. Enhanced biomimetic sequestration of $\mathrm{CO}_{2}$ into $\mathrm{CaCO}_{3}$ using purified carbonic anhydrase from indigenous bacterial strains. J. Mol. Catal. B Enzym. 2010, 67, $122-128$.

130. Sharma, A.; Bhattacharya, A.; Shrivastava, A. Biomimetic $\mathrm{CO}_{2}$ sequestration using purified carbonic anhydrase from indigenous bacterial strains immobilized on biopolymeric materials. Enzyme Microb. Technol. 2011, 48, 416-426.

131. Barbero, R.; Carnelli, L.; Simon, A.; Kao, A.; Monforte, A.D.; Ricco, M.; Bianchi, D.; Belcher, A. Engineered yeast for enhanced $\mathrm{CO}_{2}$ mineralization. Energy Environ. Sci. 2013, 6, 660-674.

132. Johnson, D.B.; Hallberg, K.B. Acid mine drainage remediation options: a review. Sci. Total Environ. 2005, 338, 3-14.

133. Faulwetter, J.L.; Gagnon, V.; Sundberg, C.; Chazarenc, F.; Burr, M.D.; Brisson, J.; Camper, A.K.; Stein, O.R. Microbial processes influencing performance of treatment wetlands: A review. Ecol. Eng. 2009, 35, 987-1004.

134. Mata, T.M.; Martins, A.A.; Caetano, N.S. Microalgae for biodiesel production and other applications: A review. Renew. Sust. Energ. Rev. 2010, 14, 217-232.

135. Schenk, P.M.; Thomas-Hall, S.R.; Stephens, E.; Marx, U.C.; Mussgnug, J.H.; Posten, C.; Kruse, O.; Hankamer, B. Second Generation biofuels: High-efficiency microalgae for biodiesel production. BioEnergy Res. 2008, 1, 20-43.

136. Chisti, Y. Biodiesel from microalgae. Biotechnol. Adv. 2007, 25, 294-306. 
137. Moheimani, N.R.; Borowitzka, M.A. The long-term culture of the coccolithophore Pleurochrysis carterae (Haptophyta) in outdoor raceway ponds. J. Appl. Phycol. 2006, 18, 703-712.

138. Environment Canada (2004) Metal Mining - Guidance Manual for Estimating Greenhouse Gas Emissions. Available online: http://publications.gc.ca/collections/Collection/En49-2-9-2E.pdf (accessed on 24 July 2013).

139. WMC Resources Ltd. 2002 Sustainability Report; WMC Resources Ltd.: London, UK, 2002. Available online: http://www.bhpbilliton.com/home/investors/reports/Documents/ wmcsustainability2002.pdf (accessed on 21 January 2014).

140. Joyce, D.; Potulski, B.C. Mt Keith Nickel Mine Centralised Tailings Disposal System. In Proceedings of 1996 National Engineering Conference: Engineering Tomorrow Today, Darwin, Australia, 21-24 April 1996; pp. 341-346.

141. Stolberg, D.J. Rehabilitation Studies on Tailings Storage Facilities in an Arid Hypersaline Region. Ph.D. Thesis, The University of Queensland, Brisbane, Australia, 2005.

142. Tchobanoglous, G.; Burton, F.L.; Stensel, H.D. Wastewater Engineering: Treatment and Reuse, 4th ed.; McGraw-Hill: New York, NY, USA, 2003.

143. Price, W.A. Guidelines and Recommended Methods for the Prediction of Metal Leaching and Acid Rock Drainage at Minesites in British Columbia; British Columbia Ministry of Employment and Investment, Energy and Minerals Division: Simthers, BC, Canada, 1997.

144. Hitch, M.; Dipple, G.M. Economic feasibility and sensitivity analysis of integrating industrial-scale mineral carbonation into mining operations. Miner. Eng. 2012, 39, 268-275.

145. Metz, B.; Davidson, O.; de Coninck, H.; Loos, M.; Meyer, L.A. IPCC Special Report on Carbon Dioxide Capture and Storage; Cambridge University Press: Cambridge, UK, 2005.

146. Ribeiro, L.A.; da Silva, P.P. Surveying techno-economic indicators of microalgae biofuel technologies. Renew. Sust. Energ. Rev. 2013, 25, 89-96.

147. Stolaroff, J.K.; Lowry, G.V.; Keith, D.W. Using CaO- and MgO-rich industrial waste streams for carbon sequestration. Energy Conv. Manag. 2005, 46, 687-699.

148. Pindyck, R.S. Pricing carbon when we don't know the right price. Regulation 2013, 36, 43-46.

149. Burgess, J.; Jeffery, L.; Lowe, A.; Schuck, S.; Flentje, W. The KPMG Green Tax Index 2013: An Exploration of Green Tax Incentives and Penalties; KPMG: Amstelveen, The Netherlands, 2013.

150. Stern, N. The Economics of Climate Change: The Stern Review; Cambridge University Press: Cambridge, UK, 2007.

151. Brennan, M.J.; Schwartz, E.S. Evaluating natural resource investments. J. Bus. 1985, 58, 135-157.

152. Brennan, M.J.; Schwartz, E.S. A new approach to evaluating natural resource investments. 1985, $3,37-47$.

153. Paddock, J.D.; Siegel, R.D.; Smith, J. Option valuation of claims on real assets: The case of offshore petroleum leases. Q. J. Econ. 1998, 103, 479-509.

154. Kelly, S. A binomial lattice approach for valuing a mining property IPO. Q. Rev. Econ. Financ. 1998, 38, 693-709.

155. Dixit, A.K.; Pindyck, R.S. Investment under Uncertainty; Princeton University Press: Princeton, NJ, USA, 1994.

156. Black, F.; Scholes, M. The pricing of options and corporate liabilities. J. Polit. Econ. 1973, 81, 637-654. 
157. Chung, C.C.; Lee, S.H.; Beamish, P.W.; Southam, C.; Nam, D. Pitting real options theory against risk diversification theory: International diversification and joint ownership control in economic crisis. J. World Bus. 2013, 48, 122-136.

158. Baker, H.K.; Dutta, S.; Saadi, S. Management views on real options in capital budgeting. J. Appl. Financ. 2011, 21, 18-29.

(C) 2014 by the authors; licensee MDPI, Basel, Switzerland. This article is an open access article distributed under the terms and conditions of the Creative Commons Attribution license (http://creativecommons.org/licenses/by/3.0/). 